$$
\begin{gathered}
\text { UNIVERSITY OF CALIFORNIA } \\
\text { COLLEGE OF AGRICULTURE } \\
\text { AGRICULTURAL EXPERIMENT STATION } \\
\text { BERKELEY, CALIFORNIA }
\end{gathered}
$$

\title{
Precooling of Fresh Fruits and Temperatures of Refrigerator Cars and Warehouse Rooms
}

E. L. OVERHOLSER and B. D. MOSES

\section{BULLETIN 496}

$$
\text { JUNE, } 1930
$$




\section{FOREWORD}

This bulletin is a contribution of the Division of Pomology, the Division of Agricultural Engineering, and the California Committee on the Relation of Electricity to Agriculture. It is the sixth of a series planned to report the results of investigations conducted jointly by the Agricultural Experiment Station, College of Agriculture, University of California, and the California Committee on the Relation of Electricity to Agriculture.* This committee represents the agricultural and electrical industries in California that are working together for the purpose of making reliable information available concerning the use of electricity on the farm, and of cooperating with similar committees in other states.

\section{B. Hutchison,}

Director, California Agricultural Experiment Station.

* The personnel of this committee for 1929-30 is:

H. B. WALKkR, College of Agriculture, Chairman.

Alex. Johnson, California Farm Bureau Federation, Vice-Chairman.

N. R. Sutherland, Pacific Gas and Electric Company, Treasurer.

B. D. Moseis, College of Agriculture, Director-Secretary.

J. R. TAVERnetTi, College of Agriculture, Field Engineer.

C. L. CoRy, College of Mechanies, University of California.

H. M. CRAWFord, Pacific Gas and Electric Company.

W. J. Delehanty, General Electric Company.

J. J. Deueu, California Farm Bureau Federation.

A. M. Frost, Great Western Power Corporation.

Charles Grunsky, Standard Management and Operating Corporation.

T. H. LAMBERT, Agriculturist.

R. C. MCFAdDEN, Southern California Edison Company.

W. C. MCWhinney, Southern California Edison Company.

E. G. Stahl, San Joaquin Light and Power Corporation.

George Tennex, McGraw-Hill Publishing Company. 


\title{
PRECOOLING OF FRESH FRUITS AND TEMPERA- TURES OF REFRIGERATOR CARS AND WAREHOUSE ROOMS
}

\author{
E. L. OVERHOLSER1 AND B. D. MOSES 2
}

The term "precooling" refers to the process of cooling the fruit soon after harvesting, and before it is shipped. The degree of maturity at which the fruit can be picked and the condition in which it arrives at its destination depend greatly upon its temperature after harvest, both before and during transit. The more nearly fruit is picked at the proper stage of maturity for the best development of color and highest subsequent eating quality, the greater is the necessity for precooling.

Fruit when picked from the tree is not inert. After harvesting it continues metabolic or ripening activities for a variable period of time, depending upon the conditions that surround it. As a result of these metabolic activities, the tissues of the fruit gradually become overripe and break down. These changes may be retarded, and decay checked, by cooling the fruit promptly after it has been harvested, and keeping it at a relatively low temperature until used. The rate at which fruit ripens may be reduced as much as one-half for each $15^{\circ}$ Fahrenheit drop in the temperature at which it is held, within ripening temperatures.

Overholser, Winkler and Jacob ${ }^{(5)}$ found that fruit exposed to the sun even while on the tree may be from $7^{\circ}$ to $10^{\circ} \mathrm{F}$ warmer than the surrounding air. Peaches have been observed to increase $1.26^{\circ} \mathrm{F}$ in ten hours when kept in air at $50^{\circ}$, and $6.57^{\circ}$ when in air at $86^{\circ} .^{(2)}$

It has been computed that sound apples held at a temperature of $68^{\circ} \mathrm{F}$ generate heat at the rate of about 0.012 calories per second per kilogram, because of their own self-heating. ${ }^{(3)}$ This amounts to about 3740 B.t.u. per ton of apples per twenty-four hours, which is sufficient heat to melt about 26 pounds of ice. Raspberries rould develop nearly five times, peaches twice, and oranges one-third as much heat as apples.

The self-heating of fruit and the relatively small amount of refrigeration required to check it, and the value of rapid reduction of field

1 Formerly Associate Professor of Pomology, University of California.

2 Associate Professor of Agricultural Engineering, University of California. 
temperatures of fruit seem to justify precooling by mechanical refrigeration, particularly when it is to be placed in insulated compartments, provided with limited refrigeration, such as refrigerator cars.

In the case of fruit to be loaded into ships, precooling enables it to be held temporarily, pending the accumulation of the cargo or the arrival of the ship, and reduces losses in case of delays resulting from unfavorable weather at sea. Precooling of fruit to be loaded also prevents the placing of warm fruit with a cargo that has been satisfactorily cooled, a procedure producing a condition favorable to mold.

It has been found that a number of rot organisms would continue to grow at $32^{\circ} \mathrm{F}$, after the spores had germinated at higher temperatures. The growth at $32^{\circ}$ is, however, not so rapid nor so extensive as at higher temperatures. The germination and growth of the spores of blue mold (Penicillium expansum), which may cause serious rotting of apples in storage, is inhibited at temperatures of $30^{\circ}$ to $32^{\circ} \mathrm{F}$. These results indicate that delay in cooling results in greater losses from rots than when the temperature is lowered quickly before the fruit is placed in storage rooms or refrigerator cars. Precooling, under many conditions, may, therefore, be expected to lessen losses from rots.

Ramsey(7) determined the average' fruit temperatures during transit between Wenatchee, Washington, and Chicago, Illinois, in a standard refrigerator car loaded with apples. He found that 114 hours, with four re-icings, were required to reduce the temperature from $62^{\circ}$ to $45^{\circ} \mathrm{F}$, the maximum temperature for the most successful shipping, and that four additional days were required to reduce it to $40^{\circ}$.

Ridley ${ }^{(9)}$ in his studies of the distribution of refrigeration in a car of strawberries en route from southwestern Missouri to St. Paul, Minnesota, found a difference of $10^{\circ} \mathrm{F}$ between the fruit in the top and that in the bottom containers. This difference is sufficient to permit marked variation in the rate of ripening or the degree of spoiling of the fruit.

In 1924 observations were conducted by The California Fruit Exchange upon fruit being shipped in standard refrigerator cars to Chicago and New York.

The temperature of the fruit throughout the top layers averaged from $9^{\circ}$ to $16^{\circ} \mathrm{F}$ higher than in the bottom layers. At the start the fruit in the top layers averaged $20^{\circ}$ higher than in the bottom layers. This condition prevailed with an outside air temperature of between $80^{\circ}$ and $90^{\circ}$ and a fruit temperature when loaded of around $75^{\circ}$ to $80^{\circ}$. The temperature of the fruit at the bottom of the load near 
the ice bunkers dropped to $45^{\circ}$ or thereabout within 12 hours after the car doors were closed, but it took four days for the temperature of the fruit in the top of the load, half way between the ice bunkers and center bracing, to drop to $55^{\circ}$.

Because of the interest shown, by shippers of California fruit, in equipment that could be used to cool the fruit before shipment, and because there seemed to be little information upon the rate at which fruit cools under different conditions, an investigation was made by the California Committee on the Relation of Electricity to

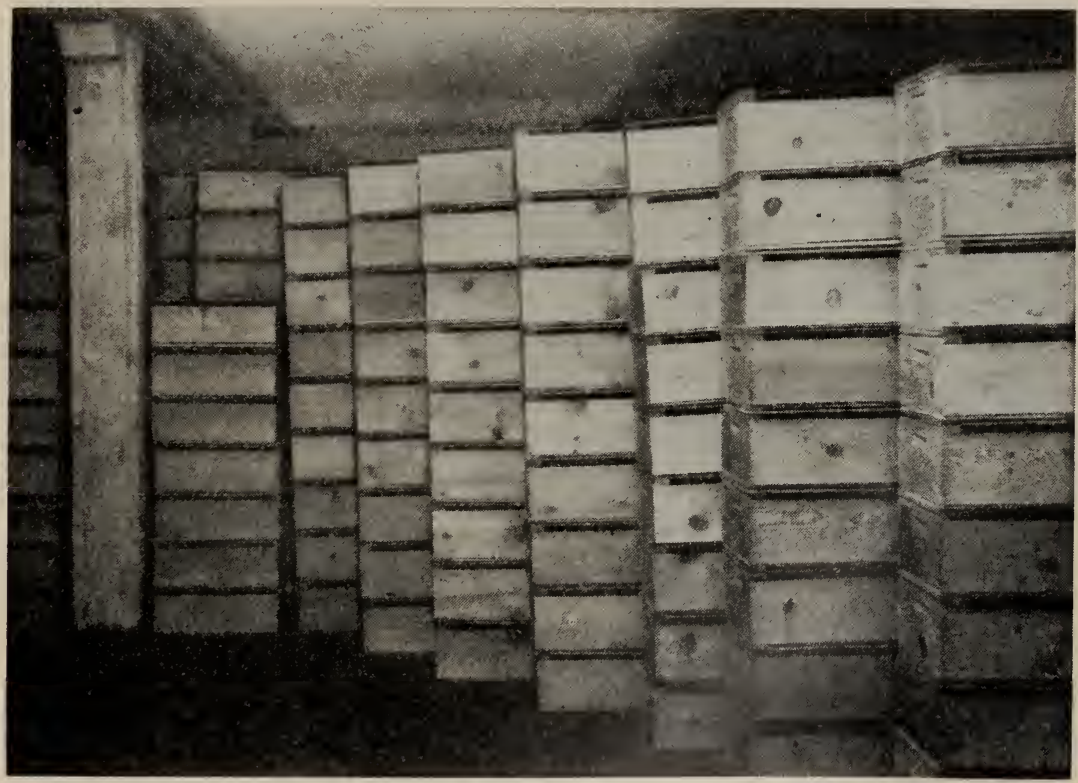

Fig. 1.-Fruit being precooled, before loading into refrigerator car, in a room in a cold storage warehouse. The fruit is placed in these rooms equipped with air ports at either end connecting with ducts through which refrigerated air is blown. The temperature ordinarily maintained in the ducts is between $28^{\circ}$ and $32^{\circ} \mathrm{F}$, and regulation is effected by controlling the flow of air.

Agriculture and by the Division of Pomology of the College of Agriculture, University of California, on the temperature changes in certain fruits as affected by different methods of precooling. This investigation covered two distictive systems, warehouse and car precooling.

Under the warehouse system the fruit is packed, placed in cold storage rooms, and cooled to between $30^{\circ}$ and $34^{\circ} \mathrm{F}$. It is then loaded directly into iced refrigerator cars, stowed in the refrigerated holds of ships, or stored in cold storage warehouses for subsequent shipment.

The air around the fruit may be cooled quickly, but the package and its contents give up their heat slowly. Under favorable con- 
ditions in a cold storage warehouse, according to Powell, ${ }^{(6)}$ the fruit in the center of a barrel of Bartlett pears stored at a temperature of $30^{\circ} \mathrm{F}$ required four to seven days to cool from $80^{\circ}$ to approximately the temperature of a cold storage room. Similar fruit in a 20-pound box or in a bushel salt crate reached $32^{\circ} \mathrm{F}$ in from 12 to 24 hours.

In a storage room approximating $32^{\circ} \mathrm{F}$, according to Whitehouse ${ }^{(11)}$ it required 30 hours for the temperature in the center of a box of wrapped apples to drop from $70^{\circ}$ to $40^{\circ} \mathrm{F}$ and an additional 130 hours to drop to $34^{\circ}$. In other words, the temperature in the box dropped $30^{\circ}$ degrees during the first 30 hours and but $6^{\circ}$ in the next 130 hours.

One of the railroad companies in southern California employs a method for car precooling which consists of hauling the loaded refrigerator cars to a central plant built along the track at a point en route, and causing cold air to be blown through each car. This air enters the hatch at one end of the car, circulates around the fruit, passes out at the other end, and returns to the cooling rooms of the plant. The direction of 'air flow may be reversed at intervals if desired. The capacity is 26 cars at a time, and the period of precooling averages about two hours. The temperature in the car may be lowered to $40^{\circ} \mathrm{F}$ in order to hasten the cooling of the cargo and lessen the need of subsequent re-icing.

Recently there has been increasing interest in portable car precoolers which enable the cars to be precooled at the point of loading. Although the details of construction and operation may differ somewhat, the various makes all employ some system of circulating air from the ice bunkers around the fruit containers. Forced air currents from fans either inside or outside the car, are controlled by air ducts, baffles, and partitions. The ice in the bunkers of the car is used to supply the refrigeration, and the circulation of the air hastens the transfer of heat from the fruit to the ice. Salt may or may not be added to the ice in the bunkers. After 6 to 8 hours of operation of the car precooler it is necessary to re-ice at the nearest icing point en route.

\section{TEMPERATURE STUDIES OF REFRIGERATOR CARS AND WAREHOUSES}

A study was made of the following: (1) air and fruit temperatures in commercial warehouse cold-storage rooms used for precooling; (2) air and fruit temperatures at different positions within the refrigerator car, as affected by car precooling; (3) the rate of tempera- 
ture drop in the fruit within the packages and in the air outside the packages; and (4) the differences in rate of temperature fall as affected by the kind of fruit and type of package.

Copper-constantan thermocouples and resistance thermometers were used for the measurements. The size of the thermocouple junctions was such that they could be inserted in even the smaller fruits, and the leads varied from 24 to 30 feet in length, so that the temperature readings could be made, by means of multiple switches, without

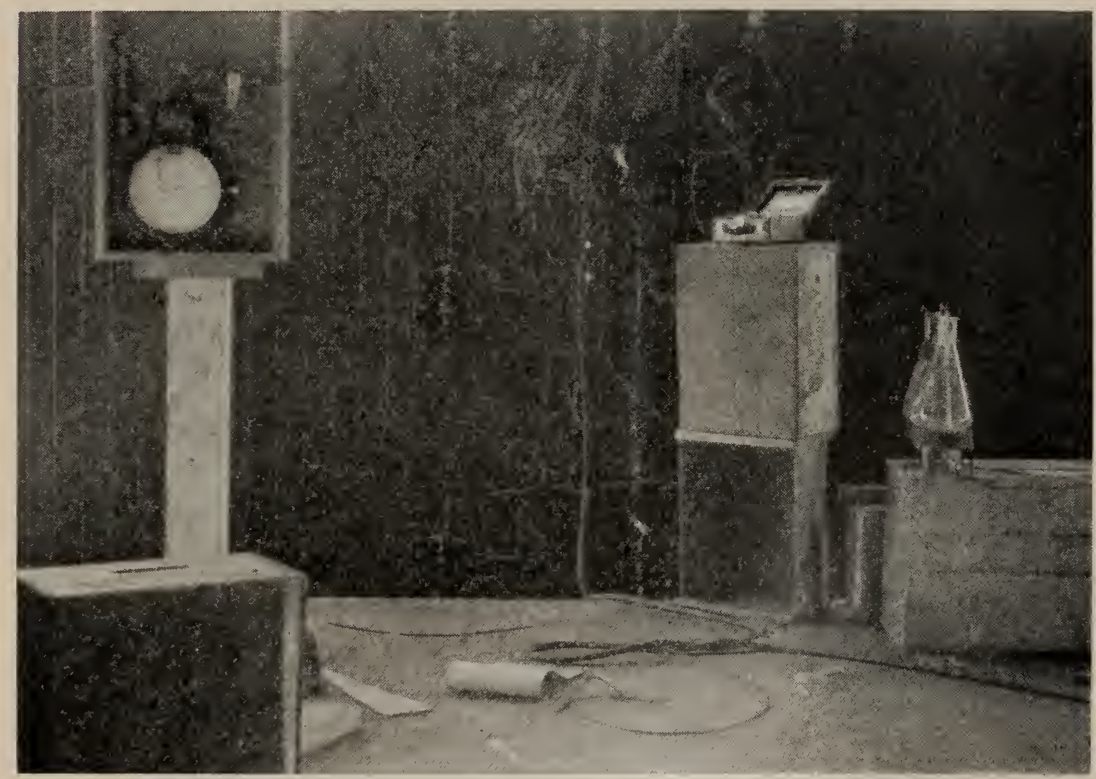

Fig. 2.-Fruit and air temperatures in a refrigerator car were taken with thermocouples attached through rotary switches to a suitable meter by leads sufficiently long to reach all parts of the car. The junctions of these couples were small enough to give the temperature at the center of a pear or even of a grape or cherry. The flexible leads permitted observations on a fruit in the center of a package in the center of a stack anywhere in the closed car. Three switches with a total capacity of 40 points were used. The leads, one of the two switches, and the meter are shown. The recording thermometer records air temperatures in the center of the car.

entering the car. Standardized mercury thermometers and recording hygro-thermographs were also used. To insure accuracy the thermocouples and resistance thermometers were carefully calibrated before and after each test. The discussion of the experimental data deals first with the warehouse precooling and second with the individual or portable car precooling units. 


\section{WAREHOUSE PRECOOLING OF PEARS, GRAPES AND ORANGES}

Pears.-One set of tests was made in a large cold storage room, which was loaded with pears to about 70 per cent of its capacity. Air at a temperature of approximately $32^{\circ} \mathrm{F}$ was continuously blown from inlet ducts into and throughout the room and its contents with sufficient velocity and volume to give a complete change of air about

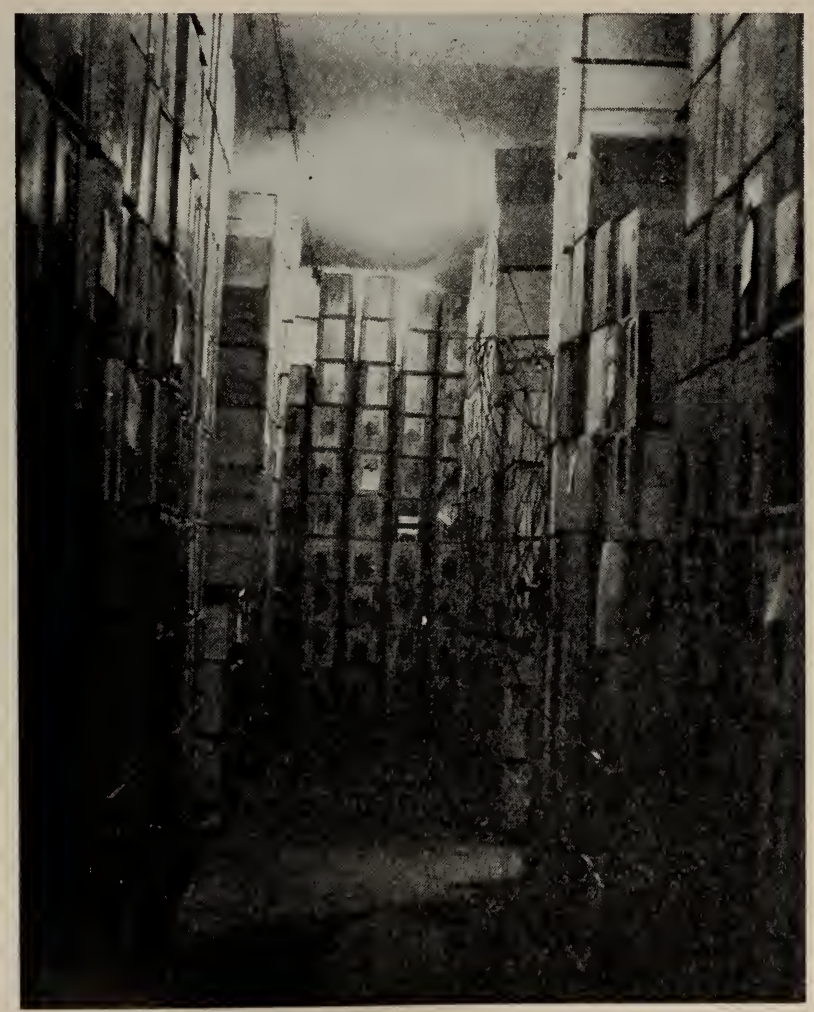

Fig. 3.-Fruit stored in cold room of cold storage plant, showing method of stacking so as to maintain aisles for handling the different lots, and the method of spacing so as to facilitate air circulation between the boxes. The wires toward the center are thermocouple leads for observing fruit and air temperatures.

every three minutes when the room was empty (see fig. 3 ). The relative humidity varied from 80 to 86 per cent at the air inlet ducts to from 89 to 91 on the air outlet side of the room, after the air had passed over the fruit.

The data in table 1 showed that it required a relatively long time to remove the heat from wrapped pears packed in the center of 
standard boxes. For example, when Bosc, Hardy, and Winter Nelis pears, having an initial temperature of about $61.5^{\circ} \mathrm{F}$, were placed in a room maintained at approximately $32^{\circ}$ to $36^{\circ}$, the fruit in the center of the boxes did not cool to $35^{\circ}$ until after 44 hours. The temperature was not further lowered after six hours' additional time.

\section{TABLE 1}

Average Rate of Teniperature Drop in the Center of Wrapped Pears and in the Space Between Pears in the Center of Packfd Boxes in Cold

Storage Precooling Rooms (San Jose, California)

\begin{tabular}{|c|c|c|c|c|}
\hline \multirow{2}{*}{\multicolumn{2}{|c|}{ Time of observation }} & \multicolumn{3}{|c|}{ Temperature in degrees Fahrenheit } \\
\hline & & \multirow{2}{*}{$\begin{array}{l}\text { In center of } \\
\text { pears in } \\
\text { center of } \\
\text { boxes }\end{array}$} & \multirow{2}{*}{$\begin{array}{l}\text { Between } \\
\text { wrapped } \\
\text { pears in center } \\
\text { of boxes }\end{array}$} & \multirow{2}{*}{$\begin{array}{l}\text { In air } \\
\text { channels } \\
\text { between } \\
\text { boxes }\end{array}$} \\
\hline Date & Hour & & & \\
\hline \multirow{6}{*}{ Sept. $15,1927 .}$. & 12:15 p.m. & 61.5 & 61.0 & 35.5 \\
\hline & $2: 12$ p.m. & 57.3 & 57.0 & 35.0 \\
\hline & 4:10 p.m. & 55.4 & 55.2 & 34.9 \\
\hline & 7:05 p.m. & 54.2 & 53.7 & 33.7 \\
\hline & 9:10 p.m. & 52.5 & 52.4 & 32.9 \\
\hline & 8:40 a.m. & 43.4 & 43.4 & 32.2 \\
\hline \multirow{2}{*}{ Sept. 16, $1927 \ldots$} & 12:45 p.m. & 41.8 & 41.1 & 33.6 \\
\hline & 5:25 p.m. & 40.2 & 40.2 & 35.3 \\
\hline \multirow{3}{*}{ Sept. $17,1927 \ldots}$. & 10:10 p.m. & 38.0 & 38.1 & 32.7 \\
\hline & 8:15 a.m. & 35.3 & 35.6 & 31.9 \\
\hline & 2:15 p.m. & 34.5 & 35.0 & 33.3 \\
\hline
\end{tabular}

There was no marked difference between the temperature drop of wrapped pears in the center of a box and that of the air immediately surrounding the fruit. Under such conditions of tight packing the cooling within the box is largely by conduction, there being little or no air movement within the package.

Stubenrauch and Ramsey ${ }^{(10)}$ determined that loose pears in lug boxes cooled to the desired temperature in less than half the time required for wrapped, packed pears. With the packed boxes it frequently required three times as long to cool the fruit in the center of the box as to cool the outer fruit in the same box. Powell ${ }^{(6)}$ reported that fruit wrappers retarded cooling, and that there may be a difference of $10^{\circ} \mathrm{F}$ in temperature of the fruit at the end of one day, between 40-pound boxes of unwrapped and of wrapped fruit. Beach and Eustace ${ }^{(1)}$ found that with barrelled apples held at $34^{\circ} \mathrm{F}$ for 74 hours, unwrapped fruit had dropped to $38.5^{\circ}$, while wrapped fruit had dropped to only $43^{\circ}$. Unwrapped fruit in a bushel box dropped to $35^{\circ}$ in 58 hours, whereas 70 hours were required for a similar drop when the fruit was wrapped. 
As shown in table 2, the temperature of the center of the fruit in the center of the box was brought to $33.2^{\circ} \mathrm{F}$ after 45 hours of cooling. The temperature of the air immediately surrounding the

\section{TABLE 2}

Rate of Temperature Drop in the Centers of Wrapped Pears and in the Space Between Pears in the Center of Packed Boxes in Precooling Warehouse Rooms (Exeter, California)

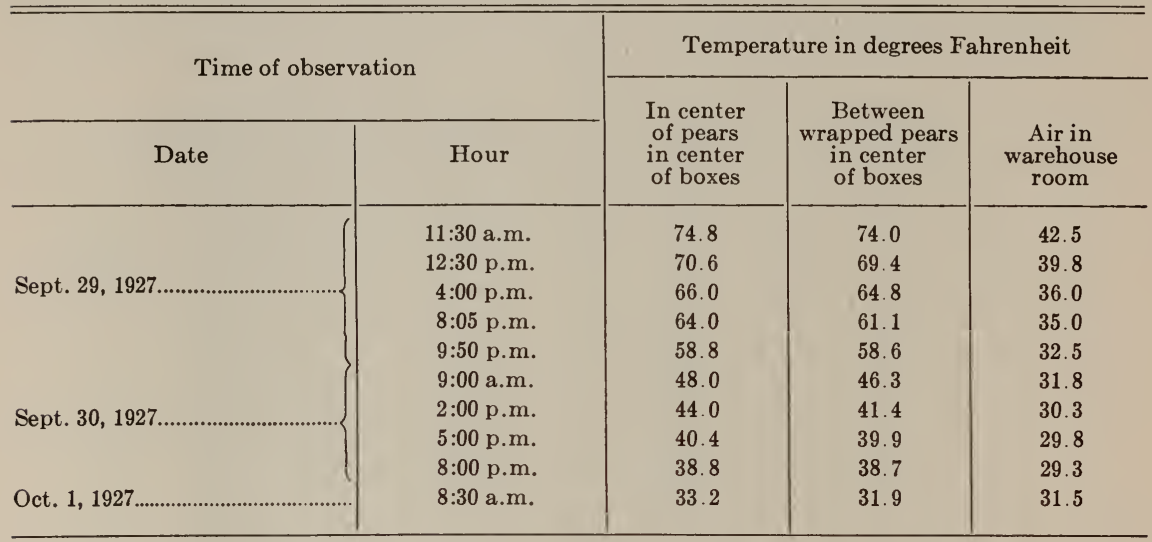

fruit in the center of the box was slightly lower than the temperature of the fruit itself, possibly because the fruit was not quite so tightly packed as was the case in the first test shown in table 1.

Grapes.-Grapes cooled somewhat more rapidly than did pears, possibly because the individual fruits were not placed so tightly

\section{TABLE 3}

Average Change of Temperature in the Center of Boxes of Black Cornichon and Malaga Grapes in Warehouse Precooling Rooms

(EXeter, CALIFornta)

\begin{tabular}{|c|c|c|c|}
\hline \multicolumn{2}{|c|}{ Time of observation } & \multicolumn{2}{|c|}{$\begin{array}{c}\text { Temperature } \\
\text { in degrees Fahrenheit }\end{array}$} \\
\hline Date & Hour & $\begin{array}{l}\text { In boxes } \\
\text { of grapes }\end{array}$ & $\begin{array}{l}\text { Air in } \\
\text { room }\end{array}$ \\
\hline \multirow{6}{*}{ Sept. $29,1927 \ldots .}$. & 11:00 a.m. & 59.5 & 40.4 \\
\hline & 12:30 p.m. & 57.4 & 39.2 \\
\hline & 4:00 p.m. & 52.9 & 36.0 \\
\hline & 8:10 p.m. & 48.1 & 35.1 \\
\hline & 9:50 p.m. & 45.5 & 32.6 \\
\hline & 9:00 a.m. & 39.6 & 31.7 \\
\hline \multirow{3}{*}{ Sept. $30,1927 \ldots}$. & 2:00 p.m. & 36.4 & 30.4 \\
\hline & 5:00 p.m. & 35.2 & 29.9 \\
\hline & 8:00 p.m. & 34.7 & 29.3 \\
\hline Oct. $1,1927 \ldots \ldots \ldots$ & $8: 30$ a.m. & 32.8 & 30.5 \\
\hline
\end{tabular}


together, were not wrapped, and were smaller. Hence, the cooling resulted not only from conduction but also to some extent from air movement between the fruits. Furthermore, the grapes, being smaller, have a larger cooling surface per unit volume than do pears, and this would permit more rapid cooling. The complete cooling required a longer time than seems usually to be believed.

The centers of boxes of Black Cornichon and Malaga grapes having a temperature of $60^{\circ} \mathrm{F}$ were cooled to $35^{\circ}$ after 30 hours in the cold storage room. It required an additional 15 hours to reduce the temperature to $33^{\circ}$. The boxes of grapes on the floor tended to cool somewhat more rapidly than did those on the top of the stack (see table 4 ).

\section{TABLE 4}

Average Change in Temperature in the Center of Boxes of Black Cornichon and Malagia Grapes in the Top and Bottom Positions in the Stacks in Warehouse Precooling Rooms (Exetter, California)

\begin{tabular}{|c|c|c|c|c|c|}
\hline \multicolumn{2}{|c|}{ Time of observation } & \multicolumn{4}{|c|}{ Temperatures in degrees Fahrenheit } \\
\hline Date & Hour & $\begin{array}{l}\text { In top } \\
\text { boxes }\end{array}$ & $\begin{array}{c}\text { In bottom } \\
\text { boxes }\end{array}$ & $\begin{array}{c}\text { Air } \\
\text { adjacent to } \\
\text { top boxes }\end{array}$ & $\begin{array}{l}\text { Air adjacent } \\
\text { to bottom } \\
\text { boxes }\end{array}$ \\
\hline \multirow{5}{*}{ Sept. $29,1927 \ldots \ldots$} & 11:00 a.m. & 63.0 & 55.3 & 42.1 & 40.0 \\
\hline & 12:15 p.m. & 59.8 & 53.2 & 39.8 & 38.5 \\
\hline & 4:00 p.m. & 53.9 & 48.2 & 36.0 & 35.4 \\
\hline & 8:10 p.m. & 49.7 & 43.8 & 35.4 & 34.7 \\
\hline & 9:50 p.m. & 48.3 & 41.3 & 33.1 & 32.5 \\
\hline \multirow{4}{*}{ Sept. $30,1927 \ldots$} & 9:00 a.m. & 42.7 & 36.3 & 31.8 & 31.6 \\
\hline & 2:00 p.m. & 37.8 & 34.2 & 30.4 & 30.3 \\
\hline & 5:00 p.m. & 33.4 & 33.9 & 29.9 & 29.8 \\
\hline & 8:00 p.m. & $3 \mathfrak{j} 1$ & 33.2 & 29.5 & 29.0 \\
\hline Oct. $1,1927 \ldots \ldots \ldots$ & $8: 30$ a.m. & 33.0 & 31.9 & 30.5 & 30.4 \\
\hline
\end{tabular}

There was a greater temperature difference between the centers of boxes of grapes at the top and at the bottom of the stacks than would be expected from the temperature differences of the air. This may, however, be explained by the differences in rate of air flow around the grapes in the two positions. A drop curtain was used to deflect the air travelling across the room through the fruit; it extended nearly the entire length of the room and reached from the ceiling to below the top boxes. The air velocity along the floor, between the stacks of fruit in the middle of the room, was 52 feet per minute, whereas six boxes above the floor it was only 5 feet per minute.

Granges.-Boxes of packed, wrapped Valencia oranges were set on end in a precooling room several feet from the nearest boxes. There were two sizes of oranges, one averaging $23 / 4$ inches in diameter, 
packing 200 to the box, and the other averaging $31 / 8$ inches in diameter and packing 126 to the box. The rate of cooling in the center of the oranges in the middle and in the periphery of the box is shown in tahle 5 .

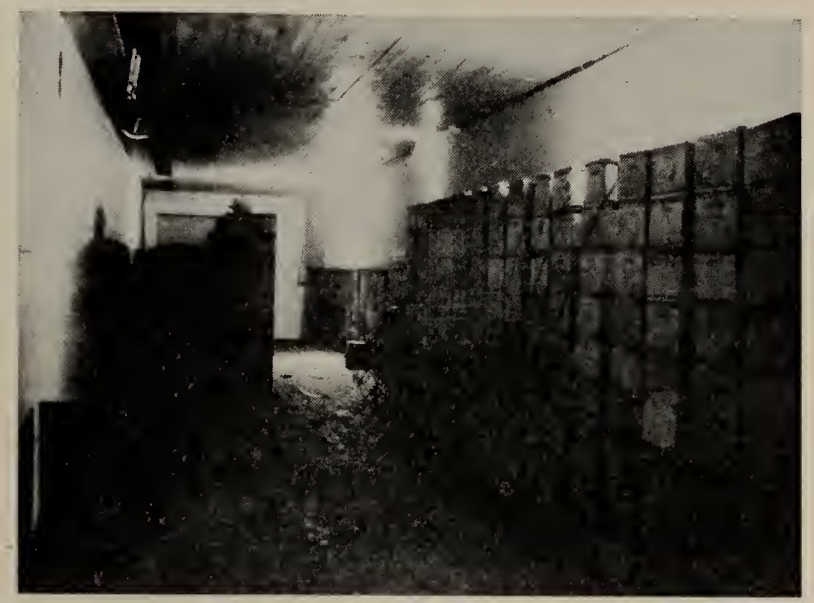

Fig. 4.-Fruit placed in cold storage room. The air enters through ports in the ceiling near one side wall, flows across the room, and passes out of ports similarly placed near the opposite wall. A canvas curtain is dropped from the ceiling to within about five feet of the floor. This curtain prevents short-circuiting of the cold air across the tops of the boxes. The wires shown are leads from thermocouples placed in the fruit and air spaces.

TABLE 5

Average Change of Temperature in the Center of Packed, Wrapped Valencia Oranges in Warehouse Preicooling Rooms (Pomona, California)

\begin{tabular}{|c|c|c|c|c|c|c|}
\hline \multirow{2}{*}{\multicolumn{2}{|c|}{ Time of observation }} & \multicolumn{5}{|c|}{ Temperature in degrees Fahrenheit } \\
\hline & & \multicolumn{2}{|c|}{$\begin{array}{c}\text { Inside of } \\
23 / 4 \text {-inch orange }\end{array}$} & \multicolumn{2}{|c|}{$\begin{array}{c}\text { Inside of } \\
31 / 8 \text {-inch orange }\end{array}$} & \multirow{2}{*}{$\begin{array}{l}\text { A verage } \\
\text { of air } \\
\text { in room }\end{array}$} \\
\hline Date & Hour & $\begin{array}{l}\text { In center } \\
\text { of one end } \\
\text { of box }\end{array}$ & $\begin{array}{l}\text { In outside } \\
\text { row of one } \\
\text { end of box }\end{array}$ & $\begin{array}{l}\text { In center } \\
\text { of one end } \\
\text { of box }\end{array}$ & $\begin{array}{l}\text { In outside } \\
\text { row of one } \\
\text { end of box }\end{array}$ & \\
\hline \multirow{6}{*}{ June $18,1928 \ldots$} & 4:00 p.m. & 74.7 & 71.0 & 73.3 & 72.3 & \\
\hline & $\begin{array}{l}\text { 4:05 p.m. } \\
\text { 5:05 p.m. }\end{array}$ & 75.3 & $\begin{array}{l}\text { Fruit p } \\
61.5\end{array}$ & $\begin{array}{c}\text { ut in cold } \\
73.5\end{array}$ & $\begin{array}{r}\text { room. } \\
65.3\end{array}$ & 35.0 \\
\hline & 7:00 p.m. & 73.8 & 56.0 & 72.5 & 58.5 & 35.0 \\
\hline & 9:00 p.m. & 71.8 & 53.0 & 70.0 & 54.8 & 34.6 \\
\hline & 7:00 a.m. & 59.0 & 44.0 & 56.5 & 44.3 & 33.3 \\
\hline & 10:00 a.m. & 55.8 & 42.3 & 53.5 & 42.3 & 33.3 \\
\hline \multirow{2}{*}{ June $19,1928 \ldots$} & \2:00 p.m. & 51.8 & 40.5 & 49.3 & 40.5 & 33.7 \\
\hline & 6:00 p.m. & 48.5 & 39.0 & 46.3 & 39.0 & 33.0 \\
\hline \multirow{6}{*}{ June $20,1928}$. & 10:00 p.m. & 45.5 & 37.3 & 43.8 & 37.5 & 32.5 \\
\hline & 7:00 a.m. & 41.0 & 35.3 & 39.3 & 35.0 & 31.8 \\
\hline & 11:00 a.m. & 39.5 & 34.8 & 37.8 & 34.5 & 32.7 \\
\hline & 3:00 p.m. & 38.8 & 34.8 & 36.8 & 34.5 & 33.3 \\
\hline & 10:00 p.m. & 36.8 & 33.8 & 35.5 & 34.3 & 33.3 \\
\hline & 8:00 a.m. & 35.3 & 33.3 & 34.5 & 33.0 & 32.5 \\
\hline
\end{tabular}


It is strikingly interesting that oranges cooled more slowly than any of the other fruit studied. Not less than 64 hours was required to cool oranges in the centers of each half of the divided box from about $74^{\circ}$ to about $35^{\circ}$, the boxes being surrounded by air of approximately $33^{\circ} \mathrm{F}$. The oranges in peripheral portions of the box cooled somewhat more rapidly than did those in the center. The relatively large size of the fruits, the high water content, and the insulating effect of the thick protective rind, no doubt account for the slowness with which oranges can be precooled.

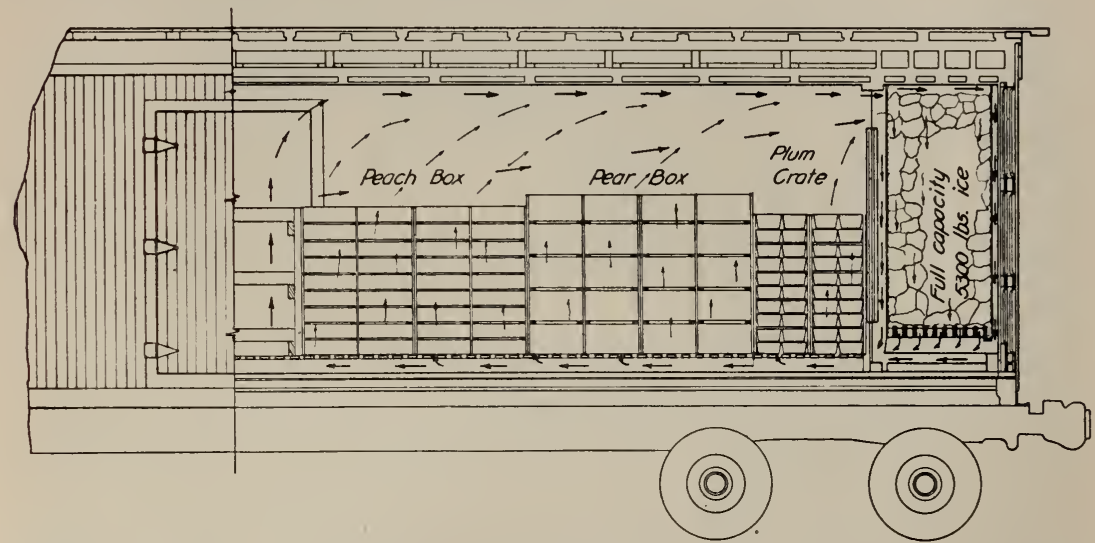

Fig. 5.- Section of refrigerator car loaded with fruit packed in containers of different shapes and sizes, showing the natural circulation of the air downward through the ice and upward through the fruit. Some precoolers (fig. 8) oppose natural convection currents and force the air to circulate in the opposite direction. Other's increase the flow in the natural direction, and still others (fig. 9) by letting the air into the car at one hatch on top of the car and out at the other, combine the two principles; in one end the air goes with the natural flow; at the other end, against it.

Several packing houses in southern California are precooling oranges. The packed oranges are placed in temperatures of from $32^{\circ}$ to $34^{\circ} \mathrm{F}$ for from three to ten days and are thus precooled to approximately $34^{\circ}$. They are then loaded directly into the iced car. The bunkers contain 23 blocks of ice weighing 315 pounds each and making about 14,500 pounds of ice to the car. After the car is loaded and braced, which requires about an hour, the hatches and doors are sealed with instructions not to re-ice en route. The precooled fruit thus begins the journey at a temperature of about $36^{\circ} \mathrm{F}$.

Through the courtesy of the California Fruit Growers' Exchange, data were obtained for 23 precooled cars shipped east from Pomona, California.

With these precooled oranges the temperature of the fruit was eleven days in gradually rising from $34^{\circ}$ to about $45^{\circ} \mathrm{F}$. There was 
relatively little difference between the fruit temperatures in the different parts of the cars en route. The difference averaged $2.5^{\circ} \mathrm{F}$. On the average the bunkers were still half full of ice when the cars reached their destinations, and the per cent of fruit decay was negligible.

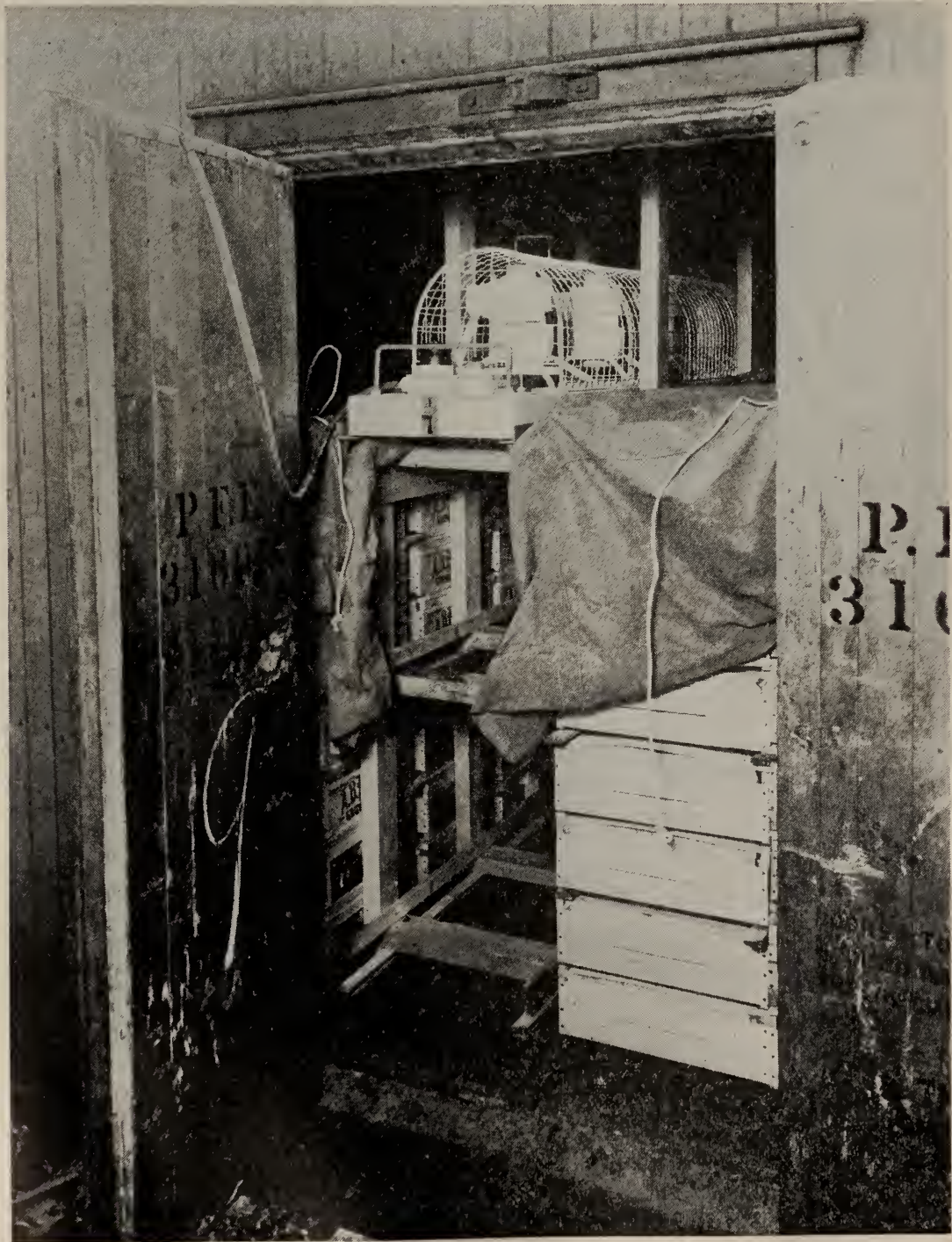

Fig. 6.-A portable car precooler consisting of four fans mounted on vertical shafts and driven by individual electric motors, mounted in a metal frame. The unit rests on the bracing at the center of the car, draws air from the ice bunkers over the fruit, and forces it downward between the boxes and toward the bunkers. 


\section{FIRST TYPE CAR PRECOOLER STUDIED}

The first type of car precooler studied consisted of four $3 / 4$-horsepower vertical electric motors directly connected with propeller fans and mounted on a horizontal carriage, which was placed in the doorway space between the bracing of a loaded car. A canvas cover was spread over the top tier in each end of the car from the bunker to the fan carriage and securely fastened in place by means of three adjustable horizontal struts which reached from side to side of the

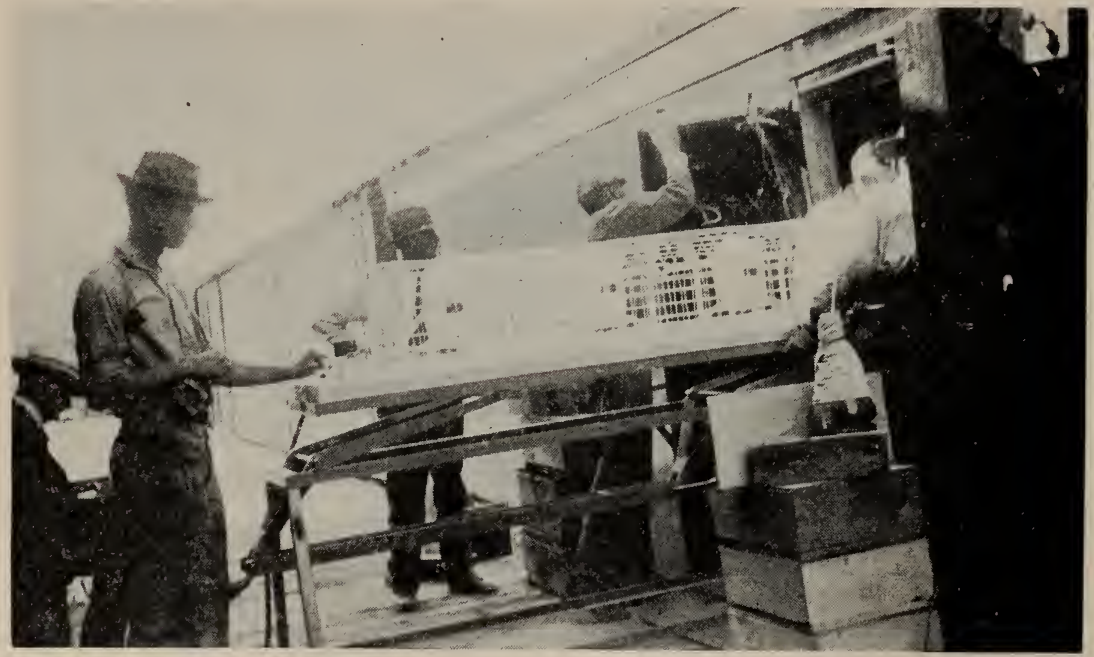

Fig. 7.-The blowers of this car precooler are carried on a special truck from which they are slid on to the bracing. The platform is adjustable as to height, and the whole frame is mounted on rockers.

car. This sheet prevented the short-circuiting of the air upwards between the tiers of boxes and directed it backwards through the fruit to the lower half of the bunkers.

When the fans are in operation, cooled air is drawn forward from the top of the ice bunkers over the canvas, forced downward at the space between the bracing, and sent backward through the tiers of boxes and around the fruit to the bottom of the ice bunkers. The warmed air then passes upward through the ice, releasing heat absorbed from the fruit, and out again at the top of the ice bunkers, to be recirculated. The theory advanced by the manufacturers in support of this direction of air flow is that the coldest air comes into contact with the warmest fruit at the center of the car, and the somewhat warmed air reaches the fruit nearest the bunkers which, under 
natural conditions, is in the coldest position of the car. The general practice is to run the precooler for from five to eight hours and to close the doors as quickly as possible when it is removed.

The car should be re-iced as soon as possible in order to replace the ice that has been melted during precooling.

Numerous tests of the air and fruit temperatures as affected by this type of car precooler were made. The refrigerator cars were all modern, fitted with standard equipment and in good condition. Some had been recently overhauled. In every case the bunkers were nearly full of ice at the time the car was loaded.

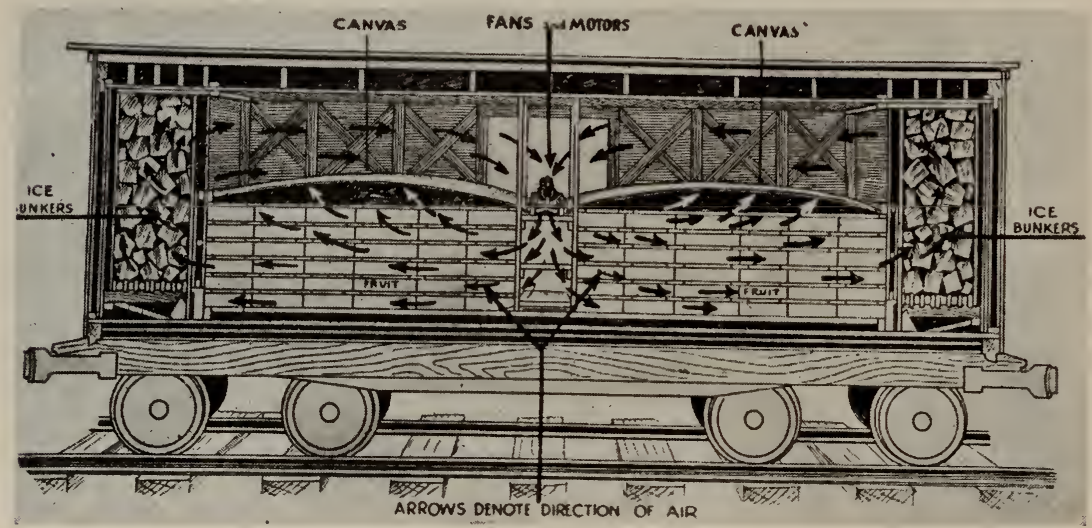

Fig. 8.- Sectional view of a standard refrigerator car with a car precooler in position. This type draws the air through the ice bunkers and then recirculates it through the load from the center of the car towards the ends. The canvas sheets prevent shortcircuiting of the air and are raised at the center because of the air pressure developed by the fans.

Air Temperatures.-The average air temperatures in different positions of the car as influenced by the operation of the car precooler were determined. Representative data, obtained from three cars, one loaded with mixed containers of plums, grapes, peaches, and pears, the second with pears, and the third with grapes, are shown in table 6 .

The data indicate that the average air temperatures, during four hours operation of the car precooler, did not drop below $45^{\circ} \mathrm{F}$.

During the operation of the precooler and afterwards the coldest air temperatures tended to be near the floor, particularly under the false floor at the bracing and at the bunker, the warmest air being found at the top of the load of fruit midway between bracing and bunker and near the bunker. The air temperature differences between various parts of the car were, however, reduced to a minimum during 
the operation of the car precooler. There was less difference in air temperature between the top and bottom of the load at the bracing than between top and bottom at the bunker. When the car precooler was stopped, however, the differences between air temperatures at the bunker, the bracing, the top, and the bottom, became marked.

TABLE 6

Air Temperaturei Changes in Standard Loaded Refrigerator Cars During and Subsequent to Operation of Car Precooler, in Degrees Fahrenheit

(Mayheivs, California, September 19, 1927)*

\begin{tabular}{c|c|c|c|c|c}
\hline $\begin{array}{c}\text { Bottom, } \\
\text { near } \\
\text { bunker }\end{array}$ & $\begin{array}{c}\text { Top, } \\
\text { near } \\
\text { bunker }\end{array}$ & $\begin{array}{c}\text { Bottom, } \\
\text { near } \\
\text { bracing }\end{array}$ & $\begin{array}{c}\text { Top, } \\
\text { near } \\
\text { bracing }\end{array}$ & $\begin{array}{c}\text { Bottom, } \\
\text { midway } \\
\text { bunker } \\
\text { and door }\end{array}$ & $\begin{array}{c}\text { Top, } \\
\text { midway } \\
\text { bunker } \\
\text { and door }\end{array}$ \\
\hline
\end{tabular}

Precooler Fans Started 1 P.M.

\begin{tabular}{l|l|l|l|l|l}
\hline 44.1 & 63.5 & 47.0 & 63.3 & 52.5 & 61.0 \\
47.1 & 54.3 & 48.3 & 52.2 & 52.9 & 52.1 \\
48.2 & 52.1 & 49.0 & 50.5 & 49.7 & 51.0 \\
46.0 & 50.5 & 47.8 & 49.0 & 46.9 & 49.7 \\
45.8 & 50.2 & 47.5 & 47.5 & 46.6 & 49.2 \\
46.0 & 50.3 & 48.0 & 47.3 & 47.3 & 49.3 \\
47.3 & 49.9 & 48.2 & 47.0 & 47.4 & 49.5 \\
45.1 & 48.5 & 45.5 & 45.5 & 48.2 & 47.1 \\
\hline
\end{tabular}

Precooler Fans Stopped 5 P.M.

\begin{tabular}{l|l|l|l|l|l}
\hline 43.9 & 48.2 & 46.2 & 49.0 & 45.8 & 49.1 \\
38.9 & 52.1 & 45.0 & 50.8 & 41.9 & 51.5 \\
38.9 & 53.2 & 45.0 & 52.0 & 41.8 & 52.8 \\
38.8 & 54.5 & 47.8 & 52.5 & 42.4 & 54.0 \\
39.0 & 55.6 & 46.8 & 525 & 42.3 & 54.3 \\
\hline
\end{tabular}

* Readings tabulated for half-hour intervals.

The temperature changes indicate definitely that when the fans were stopped there was a reversal in direction of the air currents from that during the operation of the fans.

The temperature changes within the cars were appreciably influenced, first, by the amount of ice in the bunkers, and second, by the size of the air channels formed between the cakes of melting ice. When the ice was compacted with a tamp, a slight temperature drop in the car resulted. The effect of the sun shining directly on one end of the car was indicated by the temperature measurements becoming somewhat higher there than in the opposite end.

Method of Taking Fruit Temperatures.-The studies on the temperatures of the fruit, as taken by inserting thermometers into the fruit itself, show a decided lag in the lowering of temperature of the fruit behind that of the air in the car, of the air between the 
containers, and even of the air within the containers. Each precaution taken to protect the fruit against physical injury increases the insulation of the fruit against heat removal. Thermometers placed in the air in the car, at best can be taken only as indicators, and should be placed as near the fruit as possible. Each fruit is discussed independently under the following tables.

Temperatures in Packed Pear Boxes.-Temperature measurements were made in the spaces between fruits and in the centers of pears at the bulge and center of the boxes. The data in table 7 show the lag in temperature drop just within the bulge of boxes of pears as contrasted with the air temperatures in the channels between boxes. On the other hand, after the fans were stopped, the temperature just within the bulge tended to rise more rapidly than the air temperature. This increase was probably the result of the heat of the fruit within the package.

\section{TABLE 7}

Average Rate of Temperature Drop in the Bulge of Boxes of Pears in Refrigerator Cars DURing and AFTer Operation of CAR Precooler (Mayhews, California)

\begin{tabular}{c|c|c|c}
\hline \hline \multirow{2}{*}{ Time of observation } & \multicolumn{2}{c}{$\begin{array}{c}\text { Temperature } \\
\text { in degrees Fahrenheit }\end{array}$} \\
\cline { 2 - 3 } Date & Hour & $\begin{array}{c}\text { In bulge } \\
\text { of boxes } \\
\text { of pears }\end{array}$ & $\begin{array}{c}\text { In air } \\
\text { channels } \\
\text { between } \\
\text { boxes }\end{array}$ \\
\hline Sept. 19, 1927.................. & $1: 25$ p.m. & 66.4 & 67.9 \\
\hline
\end{tabular}

Precooler Fans Started

Sept. 19, 1927................ \begin{tabular}{l|l|l}
\hline 2:30 p.m. & 62.8 & 58.1 \\
$4: 25$ p.m. & 52.8 & 46.0 \\
6:30 p.m. & 50.7 & 45.2 \\
8:30 p.m. & 48.8 & 44.3 \\
\hline
\end{tabular}

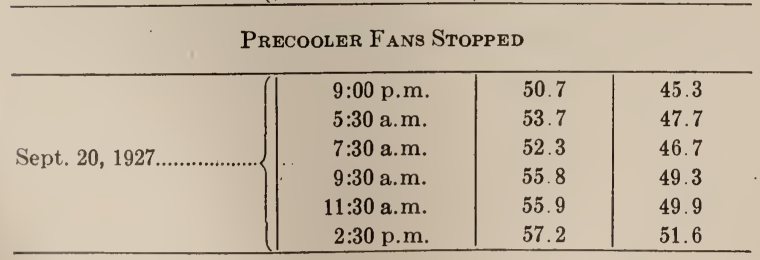

In order to determine the difference in the rate of temperature drop within the fruit itself and in the surrounding air, thermocouples were inserted into the center of wrapped pears and in the space between them as the boxes were being packed. Three such boxes were prepared and with the attached wires were placed in the tier 
second from the top and midway between the sides of a car loaded with pears. One box was placed next to the bunker midway between the sides of the car; the second box midway between the bunker and the bracing at the door; and the third at the bracing. Average temperatures for the boxes and for the air of the car are shown in table 8 .

\section{TABLE 8}

Temperature Changes in the Center of Pears Packed in Boxes and Loaded in Refrigerator Cars During and AFter Operation of Car Precooler (Mayhews, California)

\begin{tabular}{c|c|c|c|c}
\hline \hline \multicolumn{2}{c|}{ Time of observation } & \multicolumn{2}{|c}{ Average temperature in degrees Fahrenheit } \\
\cline { 2 - 5 } & Hour & $\begin{array}{c}\text { In center of } \\
\text { pears in center } \\
\text { of box }\end{array}$ & $\begin{array}{c}\text { In air } \\
\text { next to pears } \\
\text { in center } \\
\text { of box }\end{array}$ & $\begin{array}{c}\text { In air sur- } \\
\text { rounding box } \\
\text { containing } \\
\text { pears }\end{array}$ \\
\hline Date & $6: 30$ p.m. & 69.5 & 69.5 & 67.8 \\
\hline
\end{tabular}

Car Precooler Started

\begin{tabular}{|c|c|c|c|c|}
\hline $\begin{array}{l}\text { August } 20,1927 \\
\text { August } 21,1927 \ldots \ldots \ldots \ldots \ldots \ldots \ldots \ldots \ldots \ldots \ldots \ldots \ldots \ldots \ldots \ldots\end{array}$ & $\begin{array}{l}\text { 7:00 p.m. } \\
\text { 9:00 p.m. } \\
\text { 11:00 p.m. } \\
\text { 1:00 a.m. }\end{array}$ & $\begin{array}{l}67.7 \\
65.0 \\
62.0 \\
59.7\end{array}$ & $\begin{array}{l}67.0 \\
64.5 \\
61.8 \\
59.2\end{array}$ & $\begin{array}{l}59.9 \\
48.5 \\
45.0 \\
43.3\end{array}$ \\
\hline
\end{tabular}

Car Precooler Stopped

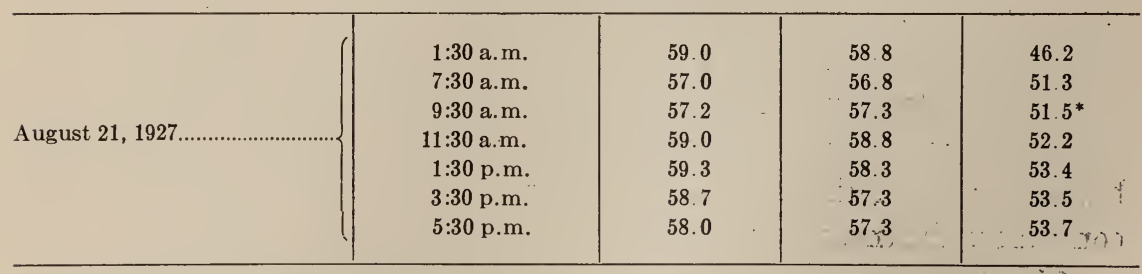

* Six thousand pounds of ice added to car bunkers.

A test was also conducted with a car containing plums and grapes as well as pears. The temperature of the pears in the mixed car did not drop so satisfactorily as in the cars loaded with pears only. The difference in the size of the boxes necessitated loading in such a manner that continuous air channels extending from the bunkers to the bracing and from the floor to the top of the load could not be left between the rows of boxes. The temperature measurements indicated that loading, stripping, and bracing, so as to form continuous air channels, facilitate the lowering of the temperatures uniformly and effectively during and after the operation of the car precooler. These data are shown in table 9. 
TABLE 9

Changes in Temperature in the Ceinter of Packed Pears in a Mixed Refrigkrator Car Containing also Plums and Grapes, During and After Operation of Car Precooler. (Mayhews, California)

\begin{tabular}{|c|c|c|c|c|}
\hline \multirow{2}{*}{\multicolumn{2}{|c|}{ Time of observation }} & \multicolumn{3}{|c|}{ Average temperature in degrees Fahrenheit } \\
\hline & & \multirow{2}{*}{$\begin{array}{l}\text { In center of } \\
\text { pears in center } \\
\text { of box }\end{array}$} & \multirow{2}{*}{$\begin{array}{l}\text { In air } \\
\text { next to pears } \\
\text { in center } \\
\text { of box }\end{array}$} & \multirow{2}{*}{$\begin{array}{l}\text { In air sur- } \\
\text { rounding box } \\
\text { containing } \\
\text { pears }\end{array}$} \\
\hline Date & Hour & & & \\
\hline \multicolumn{5}{|c|}{ Precooler Fans Started } \\
\hline August $20,1927 \ldots$ & $\begin{array}{l}\text { 2:30 p.m. } \\
\text { 4:25 p.m. } \\
\text { 6:30 p.m. } \\
\text { 8:30 p.m. }\end{array}$ & $\begin{array}{l}67.5 \\
66.5 \\
650 \\
635\end{array}$ & $\begin{array}{l}67.5 \\
65.5 \\
62.0 \\
60.5\end{array}$ & $\begin{array}{l}58.5 \\
44.0 \\
44.0 \\
42.0\end{array}$ \\
\hline \multicolumn{5}{|c|}{ Precooler Fans Stopped } \\
\hline August $21,1927 \ldots$ & $\begin{array}{r}9: 00 \text { p.m. } \\
\text { 9:30 a.m. } \\
\text { 11:30 a.m. } \\
\text { 2:30 p.m. }\end{array}$ & $\begin{array}{l}63.0 \\
61.5 \\
61.5 \\
62.5\end{array}$ & $\begin{array}{l}60.5 \\
60.0 \\
61.0 \\
61.5\end{array}$ & $\begin{array}{l}45.0 \\
51.0 \\
52.0 \\
56.0\end{array}$ \\
\hline
\end{tabular}

These observations agree with those of McKay ${ }^{(4)}$ who pointed out that loading different styles of packages together in one end of the car obstructs air circulation and seriously retards refrigeration. The natural circulation of cold air from the ice bunkers through the load is, at best, slow and if open spaces are not left between the rows of packages, to provide channels for the flow of cold air from the bunkers toward the alley at the center of the car, the cooling of the containers farthest from the bunkers is materially retarded.

The temperature of the air in the car tended to rise gradually after the precooler was stopped, but during the period of observation it remained below that of the fruit; the temperature of the fruit in the center of the box, however, continued to drop slowly for some time. The temperature of the air adjacent to the pears tended to be slightly below that of the fruit.

Temperatures in Packed Grape Boxes.-Temperature measurements were taken also of grapes loaded in refrigerator cars, as affected by this method of car precooling. Thermocouples were placed between the grapes packed in standard boxes, but not within the individual berries. There was an appreciable drop in temperature of the grapes in the car during loading; the cooling was more rapid during the operation of the precooler; and lower temperatures were reached than 
was found to be the case with wrapped packed pears. The air temperature in the car of grapes did not, however, become so low as that in the car of pears, probably because the air was more completely circulated about the grapes, thus effecting a more rapid transfer of heat.

TABLE 10

Thanges in Temperature in Packed Grape Boxes in Refrigerator Car, During ańd A fiter Operation of Car Preicooler (Sept. 1, 1927,

MaYhews, California)

\begin{tabular}{l|l|c}
\hline \hline \multirow{2}{*}{ Time of observation } & \multicolumn{2}{|c}{$\begin{array}{c}\text { Average temperatures } \\
\text { in degrees Fahrenheit }\end{array}$} \\
\cline { 2 - 3 } & $\begin{array}{l}\text { In center of } \\
\text { grape boxes }\end{array}$ & $\begin{array}{c}\text { In air } \\
\text { channels }\end{array}$ \\
\hline
\end{tabular}

\begin{tabular}{|c|c|c|}
\hline \multicolumn{3}{|c|}{ Precooler Fans Started } \\
\hline 1:50 p.m. & 60.8 & 54.2 \\
\hline $2: 45$ p.m. & 56.3 & 51.3 \\
\hline 3:45 p.m. & 55.4 & 52.3 \\
\hline 4:45 p.m. & 51.5 & 49.3 \\
\hline \multicolumn{3}{|c|}{ Precooler Fans Stopped } \\
\hline 5:10 p.m. & 52.9 & 50.4 \\
\hline 7:50 p.m. & 52.3 & 51.3 \\
\hline
\end{tabular}

As shown in table 10, the average temperature in the centers of packed grape boxes was lowered approximately $9^{\circ} \mathrm{F}$, with only three hours' operation of the car precooler. This drop in fruit temperature was within about $2^{\circ}$ of the air temperature surrounding the boxes. The temperature change within a 3-hour interval after the precooler fans were stopped, was insignificant.

Temperatures in Packed Boxes of Cherries.-In the study of cooling cherries, small thermocouple points were inserted into the flesh to the pits of cherries packed in the centers of each end of standard cherry boxes. These boxes were placed in the top and bottom layers at the bunker, at the bracing, and midway between bunker and bracing positions in the car. Data showing the temperature drop in the packed cherries and in the air surrounding the boxes as affected by car precooling, are shown in table 11 .

In the case of packed cherries, the car precooler lowered the temperature of the fruit from $60^{\circ} \mathrm{F}$ to $43.3^{\circ}$, or a drop of nearly $17^{\circ}$ in six hours' operation. This is greater than was obtained with either 
pears or grapes, but less than with apricots. The average air temperature in the car was lowered from $56^{\circ}$ to $41.4^{\circ}$. As contrasted with the other experiments the initial fruit and outside air temperatures were relatively low. This may account at least partially for the lower final temperatures attained. Furthermore, the small size of the container and of the individual specimens of fruit no doubt permitted more effective cooling. As opposed to this, however, the tightness with which the individual cherries are fitted into the pack retarded cooling as contrasted with that of apricots.

\section{TABLE 11}

Temperature Changes in the Centers of Packed Cherries Loaded in Refrigerator Cars, During Operation of Car Precooler

(VACAVille, May 15, 1928)

\begin{tabular}{c|c|c}
\hline \multirow{2}{*}{ Time of observation } & \multicolumn{2}{|c}{$\begin{array}{c}\text { Average temperatures, } \\
\text { degrees Fahrenheit }\end{array}$} \\
\cline { 2 - 3 } & $\begin{array}{c}\text { In center } \\
\text { of cherries } \\
\text { in center of } \\
\text { packed boxes }\end{array}$ & $\begin{array}{c}\text { In air } \\
\text { channels } \\
\text { surrounding } \\
\text { boxes }\end{array}$ \\
\hline 2:50 p.m. & 62.2 & 62.4 \\
\hline \multicolumn{2}{|c}{ PrECOOLER STARTED } \\
\hline \multicolumn{2}{|c}{} \\
3:10 p.m. & 60.0 & 56.0 \\
4:00 p.m. & 58.0 & 52.2 \\
5:00 p.m. & 53.9 & 48.2 \\
6:00 p.m. & 48.5 & 44.8 \\
7:00 p.m. & 45.7 & 43.0 \\
8:00 p.m. & 44.6 & 42.8 \\
9:00 p.m. & 43.3 & 41.4 \\
\multicolumn{2}{c}{ PreCOOLER STOPPED } \\
\hline
\end{tabular}

Temperatures in Packed Crates of Apricots.-In a manner similar to that employed with cherries, temperature measurements were made with apricots in the standard pack of four 5-pound baskets in a crate. The data are shown in table 12 .

With packed apricots, three and one-half hours' operation of the car precooler lowered the temperature of the fruit from $78^{\circ}$ to $64.4^{\circ} \mathrm{F}$, or a drop of nearly $14^{\circ}$. Simultaneously the average air temperature in the car was lowered from $64.2^{\circ}$ to $53.4^{\circ}$. The cooling of the apricots was favored by the somewhat open type of container and by comparatively large free air spaces, which permitted freer air circulation immediately around each fruit. 


\section{TABLE 12}

Temperature: Changes in thei Centers of Packed Apricots, Loaded in Refrigerator Cars, During Operation of Car Preicoller (June 5, 1928, VaCaville, California)

\begin{tabular}{|c|c|c|}
\hline \multirow{2}{*}{$\begin{array}{l}\text { Time of } \\
\text { observation }\end{array}$} & \multicolumn{2}{|c|}{$\begin{array}{l}\text { Average temperature } \\
\text { in degrees Fahrenheit }\end{array}$} \\
\hline & $\begin{array}{c}\text { In center } \\
\text { of apricots } \\
\text { in center of } \\
\text { baskets packed } \\
\text { in crates }\end{array}$ & $\begin{array}{c}\text { In air } \\
\text { channels } \\
\text { surrounding } \\
\text { crates }\end{array}$ \\
\hline 1:00 p.m. & 79.2 & 75.3 \\
\hline \multicolumn{3}{|c|}{ Precooler Started } \\
\hline $\begin{array}{l}\text { 1:25 p.m. } \\
\text { 2:25 p.m. } \\
\text { 3:25 p.m. } \\
\text { 4:25 p.m. } \\
\text { 4:55 p.m. }\end{array}$ & $\begin{array}{l}78.0 \\
75.9 \\
70.0 \\
66.5 \\
64.4\end{array}$ & $\begin{array}{l}64.2 \\
59.4 \\
55.9 \\
54.5 \\
53.4\end{array}$ \\
\hline \multicolumn{3}{|c|}{ Precooler Stopped } \\
\hline
\end{tabular}

Temperatures in Packed Boxes of Peaches.-In a manner similar to that employed with the other fruits, temperature measurements were made simultaneously in two refrigerator cars loaded with Levy peaches wrapped and packed in standard boxes. One of the cars was iced and used a car precooler, while the other was iced only. The air temperatures outside the cars were relatively cool and without much fluctuation, averaging about $60^{\circ} \mathrm{F}$. The data are shown in table 13 .

\section{TABLE 13}

Comparison of Temperature Changes in the Centers of Packed Peaches LOADED IN REFrigeratOR CARS, ONE ICED ONLY, THE OTHER ICED AND WITH Car Precooler in Operation (Sept. 12, 1928, Loomis, California)

\begin{tabular}{|c|c|c|c|c|}
\hline \multirow{3}{*}{$\begin{array}{l}\text { Time of } \\
\text { observation }\end{array}$} & \multicolumn{4}{|c|}{ Average temperature in degrees Fahrenheit } \\
\hline & \multicolumn{2}{|c|}{$\begin{array}{l}\text { In centers of peaches } \\
\text { in center of boxes }\end{array}$} & \multicolumn{2}{|c|}{$\begin{array}{l}\text { In air channels } \\
\text { surrounding boxes }\end{array}$} \\
\hline & Ice only & $\begin{array}{l}\text { Ice and car } \\
\text { precooler }\end{array}$ & Ice only & $\begin{array}{l}\text { Ice and car } \\
\text { precooler }\end{array}$ \\
\hline 11:15 a.m. & 56.0 & 60.0 & 52.9 & 44.0 \\
\hline 1:15 p.m. & 52.6 & 51.8 & 49.3 & 40.8 \\
\hline 3:15 p.m. & 53.4 & 50.4 & 49.3 & 41.4 \\
\hline 5:15 p.m. & 54.2 & 48.3 & 49.7 & 40.2 \\
\hline 7:15 p.m. & 54.2 & 45.8 & ……................. & 38.6 \\
\hline 8:15 p.m. & 54.2 & 44.6 & & 37.8 \\
\hline
\end{tabular}


During the nine hours that the cars were under observation the temperature drop of the peaches in the car, without the precooler, was less than $2^{\circ}$, while that in the car using the precooler was over $15^{\circ}$. Apparently the refrigeration capacity of the first car was nearly all used in preventing a temperature rise due to self-heating of the fruit.

\section{SECOND TYPE CAR PRECOOLER STUDIED}

The second type of car precooler studied made use of a large fan blower mounted outside the car. The air from the blower was led to one of the hatches at one end of the car by means of a large canvas

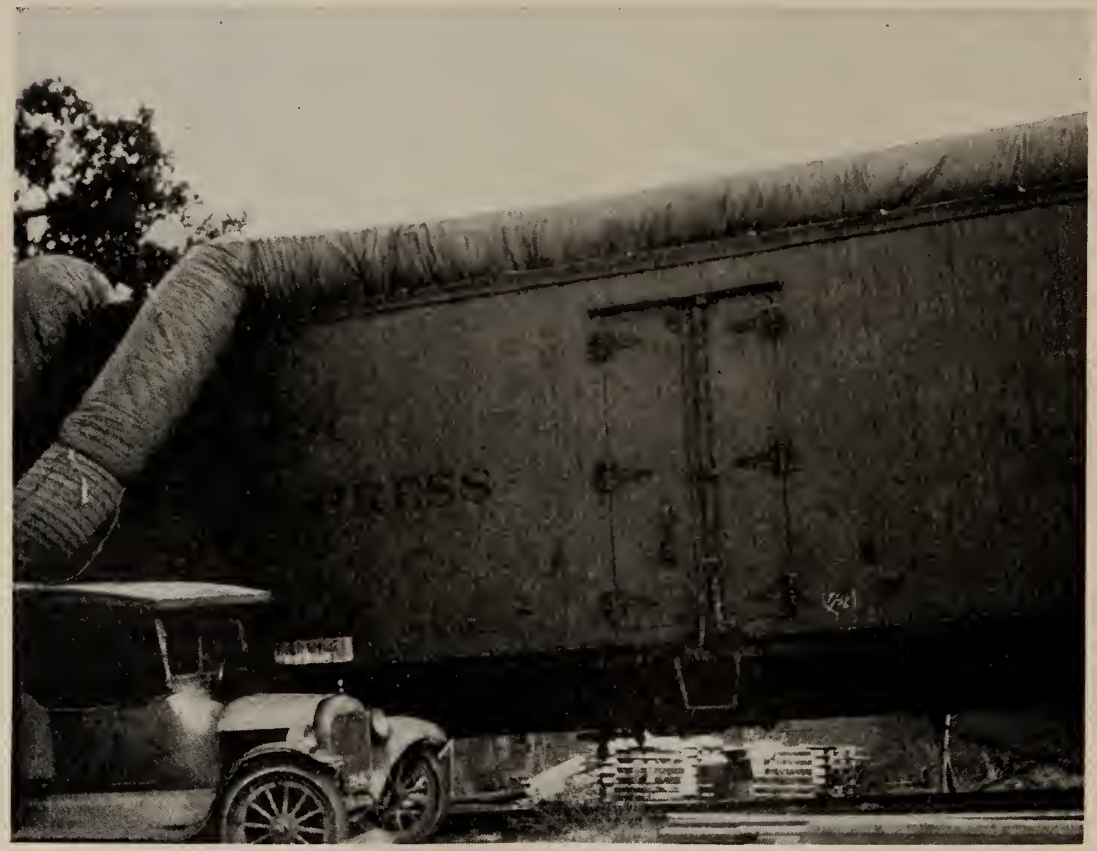

Fig. 9.-A portable type of car precooler using collapsible canvas air ducts and portable blower for circulating the air through the ice bunkers and fruit compartment of the standard refrigerator car. The air is drawn out of one hatch at one end of the car by a power-driven blower mounted on a truck and forced down through one of the hatches at the other end of the car.

pipe and was returned from a hatch at the opposite end by a similar pipe reinforced to prevent collapsing. Within the car, the air from the inlet hatch was forced downward through the ice, out at the bottom of the bunker, through the fruit to the bottom of the other bunker, and up through the ice to the outlet hatch. The short-circuiting of the air across the top of the load was prevented by tacking canvas 
over the openings in the bulkhead at each end of the car. Observations were made with this type of car precooler upon tomatoes and cantaloupes in southern California.

Temperatures in Packed Boxes of Tomatoes.-Tests were made near Ojai, California, on a car of packed, hard, green tomatoes, by placing thermocouples in the air spaces and within some of the tomatoes. The car was loaded and braced by 5 o'clock in the afternoon, 75 pounds of salt were added to the ice of the air inlet bunker, and the precooler was connected with the hatches (fig. 9), the engine being started at 6 o'clock. The outside air temperature at this time was $72^{\circ} \mathrm{F}$, but dropped rapidly after sunset. The temperature of the tomatoes as they were loaded varied from $68^{\circ}$ to $78.8^{\circ}$, with an average temperature of $71.8^{\circ}$. The data showing the average air and fruit temperatures during the operation of the car precooler are given in table 14 .

TABLE 14

Temperature Changes in the Centers of Packed Tomatoes, Loaded in Refrigerator Cars, During Operating of Car Precooler.

(OCTOBER 3, 1927, OJAI, CALIFORNIA)

\begin{tabular}{c|c|c|c}
\hline \hline & \multicolumn{3}{|c}{ Temperatures in degrees Fahrenheit } \\
\hline $\begin{array}{c}\text { Time of } \\
\text { observation }\end{array}$ & $\begin{array}{c}\text { In center } \\
\text { of tomatoes }\end{array}$ & $\begin{array}{c}\text { In air channels } \\
\text { between stacks }\end{array}$ & $\begin{array}{c}\text { In air } \\
\text { in bunker }\end{array}$ \\
\cline { 2 - 3 } & 71.8 & 63.5 & 40.8 \\
6:00 p.m. & 68.4 & 49.4 & 35.5 \\
6:30 p.m. & 65.4 & 46.6 & 34.5 \\
7:40 p.m. & 62.6 & 46.2 & 43.3 \\
9:30 p.m. & 61.3 & 45.5 & 42.8 \\
10:30 p.m. & 60.1 & 44.4 & 32.8 \\
11:05 p.m. & & & \\
\hline
\end{tabular}

At the close of the five-hour period during which the car precooler was in operation, the temperature of the packed tomatoes varied from $55^{\circ}$ to $64^{\circ}$, depending upon the position of the box in the car and of the tomatoes in the box, those on the outside of the package being cooler than those near the center: the average drop in temperature of the tomatoes was, however, somewhat over $11^{\circ}$.

Temperatures in Packed Crates of Cantaloupes.-In one of the tests made at Brawley, California, the car was iced at $9: 30$ P.M. of one day, re-iced at 8:45 the following morning, and loaded throughout the day with crates of "choice", (mature and ready to eat) cantaloupes. When the car precooler was started, the bunkers contained about 7,000 pounds of ice, to which approximately 150 pounds of coarse salt had been added. Average data obtained are presented in table 15 . 
As shown in table 15, the average initial temperature of the cantaloupes was $75.2^{\circ} \mathrm{F}$ and after six hours' operation of the car precooler it was $54.8^{\circ}$, or about $20^{\circ}$ lower. This resulted in the reduction of ice in the intake bunker from about three-fourths full to one-eighth full, and in the outlet bunker from three-fourths to two-fifths.

\section{TABLE 15}

Average Temperature Changes During Operation of Car. Precooler at the Centeirs of Packed Cantaloupes in the Centers of Crates loaded in Refrigerator Cars (June 12, 1928, Brawley, California)

\begin{tabular}{|c|c|c|c|}
\hline \multirow{2}{*}{$\begin{array}{c}\text { Time of } \\
\text { observation }\end{array}$} & \multicolumn{3}{|c|}{ Average temperatures in degrees Fahrenheit } \\
\hline & In melon & In air in car & Average outside of car in shade \\
\hline $\begin{array}{l}\text { 5:30 p.m. } \\
\text { 5:40 p.m. } \\
\text { 5:45 p.m. } \\
\text { 5:45 p.m. } \\
\text { 6:00 p.m. } \\
\text { 7:00 p.m. } \\
\text { 7:05 p.m. } \\
\text { 8:00 p.m. } \\
\text { 8:30 p.m. } \\
\text { 9:00 p.m. } \\
\text { 10:00 p.m. } \\
\text { 11:00 p.m. } \\
\text { 11:30 p.m. } \\
\text { 12:00 a.m. } \\
\text { 12:05 a.m. } \\
\text { 12:40 a.m. }\end{array}$ & $\begin{array}{c}79.8 \\
\text { Car doors closed. } \\
78.3 \\
\text { Precooler started. } \\
75.2 \\
68.4 \\
\text { Ice tamped down in each } \\
64.4 \\
\text { Ice tamped down; } 100 \\
61.5 \\
59.1 \\
56.9 \\
\text { Ice tamped down; } 125 \\
54.8 \\
\text { Precooler stopped. } \\
55.9\end{array}$ & 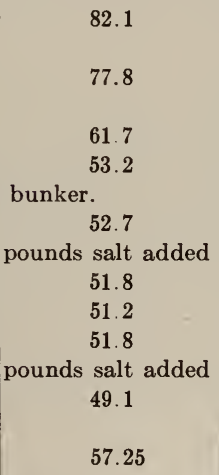 & \begin{tabular}{|l}
97 \\
96 \\
95 \\
90 \\
84 \\
to bunkers. Inlet $1 / 3$ full; \\
85 outlet $3 / 5$ full. \\
80 \\
81.5 \\
to bunkers. Inlet $1 / 8$ full. \\
80 outlet $2 / 5$ full. \\
79
\end{tabular} \\
\hline
\end{tabular}

In another test the car was iced at 8:30 P.M. of one day and loaded with crates of "choice" and "fancy" (half-ripe) cantaloupes on the following day. The bunkers were about five-eighths full of ice when the car precooler was put into operation in the afternoon. Approximately 250 pounds of salt were initially added. The outside air temperatures were somewhat higher than those during the first test, and the period of precooling was slightly longer. The data are averaged in table 16 .

The data in table 16 are comparable with those presented in table 15 , except that the temperatures attained were not quite so low, possibly because the car was not re-iced before the operation of the car precooler, and because the outside air was a few degrees warmer.

As shown in tables 15 and 16, the ice in the bunker at the inlet duct melted more rapidly than at the outlet; hence, where feasible, the direction of air currents should be reversed so as to make the best use of the ice. Data showing the temperature changes effected by 


\section{TABLE 16}

Average Temperature Changes During Operation of Car Precooler, at the Centers of Packed Cantaloupes, in the Centers of Crates loaded in Reirighator Cars (June 22, 1928, Brawlex, California)

\begin{tabular}{|c|c|c|c|}
\hline \multirow{2}{*}{$\begin{array}{c}\text { Time of } \\
\text { observation }\end{array}$} & \multicolumn{3}{|c|}{ A verage temperatures in degrees Fahrenheit } \\
\hline & In melon & In air in car & Air outside of car in shade \\
\hline $\begin{array}{l}\text { 4:00 p.m. } \\
\text { 4:15 p.m. } \\
\text { 4:20 p.m. } \\
\text { 5:10 p.m. } \\
\text { 5:15 p.m. } \\
\text { 6:00 p.m. } \\
\text { 7:00 p.m. } \\
\text { 8:00 p.m. } \\
\text { 8:30 p.m. } \\
\text { 9:00 p.m. } \\
\text { 10:00 p.m. } \\
\text { 11:10 p.m. } \\
\text { 11:30 p.m. } \\
\text { 11:40 p.m. } \\
\text { 11:45 p.m. }\end{array}$ & $\begin{array}{l}77.7 \\
\text { Precooler started. } \\
76.2 \\
\text { Ice tamped down; } 50 \\
73.4 \\
72.3 \\
69.9 \\
67.7 \\
\text { Ice tamped down; } 50 \\
65.4 \\
63.0 \\
\text { Ice tamped down; } 125 \\
61.0 \\
\\
\text { Precooler stopped. } \\
60.7\end{array}$ & $\begin{array}{c}81.1 \\
68.9 \\
\text { pounds salt added } \\
59.5 \\
55.8 \\
53.8 \\
52.3 \\
\text { pounds salt added } \\
50.1 \\
49.8 \\
\text { pounds salt added } \\
48.6\end{array}$ & \begin{tabular}{|}
104 \\
104 \\
to inlet bunker. Ice about same. \\
102 \\
100 \\
93 \\
91 \\
to inlet bunker. Inlet $2 / 5$ full; \\
90 outlet $1 / 2$ full. \\
86 \\
to both bunkers. 1 foot ice left \\
in inlet. \\
$82 \quad 2$ feet of ice left \\
in outlet.
\end{tabular} \\
\hline
\end{tabular}

\section{TABLE 17}

Average Temperature Changes During Operation of Car Precooler, at the Centers of Packed Cantaloupeis, in thei Centers of Crates Loaded in Refrigerator Caris (June 25, 1928, Brawley, California)

\begin{tabular}{|c|c|c|c|}
\hline \multirow{3}{*}{$\begin{array}{l}\text { Time of } \\
\text { observation }\end{array}$} & \multicolumn{3}{|c|}{ Average temperatures in degrees Fahrenheit } \\
\hline & \multicolumn{2}{|c|}{ Inside of car } & \multirow{2}{*}{$\begin{array}{l}\text { In air outside of } \\
\text { car in shade }\end{array}$} \\
\hline & In melon & In air & \\
\hline $\begin{array}{l}\text { 2:30 p.m. } \\
\text { 2:40 p.m. } \\
\text { 2:45 p.m. } \\
\text { 3:40 p.m. } \\
\text { 3:45 p.m. } \\
\text { 5:00 p.m. } \\
\text { 6:00 p.m. } \\
\text { 6:27 p.m. } \\
\text { 6:42 p.m. }\end{array}$ & $\begin{array}{c}75.2 \\
\text { Precooler started. } \\
72.1 \\
\text { Ice tamped down; bunke } \\
65.2 \\
60.3 \\
56.8 \\
\text { Precooler stopped; doors } \\
\text { Ice tamped down; } 75 \text { pou } \\
150 \text { pounds salt added to } \\
\text { full of ice; and new out } \\
54.6 \\
52.25 \\
\text { Ice tamped down in new } \\
50.0 \\
46.9 \\
\text { Precooler stopped. } \\
47.0\end{array}$ & \begin{tabular}{|c|}
84.5 \\
73.0 \\
rs $7 / 8$ full of ice. \\
57.3 \\
53.4 \\
49.1 \\
opened; direction of air cur \\
nds salt added to inlet bun \\
outlet bunker (now inlet bu \\
let bunker $1 / 2$ full of ice. \\
51.4 \\
46.4 \\
inlet bunker. \\
44.9 \\
42.8 \\
43.8
\end{tabular} & $\begin{array}{l}\qquad 105 \\
105 \\
106 \\
106 \\
98 \\
\text { rent reversed. } \\
\text { ker (now outlet bunker); } \\
\text { nker); new inlet bunker } 3 / 4 \\
\\
97 \\
96 \\
94 \\
88 \\
88\end{array}$ \\
\hline
\end{tabular}


reversing the air currents are presented in table 17 . About 100 pounds of salt were added to the bunkers just before starting the car precooler.

The data in table 17 indicate that reversing the air currents aids the cooling of cantaloupes.

\section{COMPARISON OF DIFFERENT SYSTEMS}

From the standpoint of temperature conditions, cold storage warehouses provide the best method of precooling fruit. The use of refrigerating machinery for cooling the circulating air and the accurate temperature control are most effective in removing the heat from fruit placed in cooling rooms. These warehouses carry on a successful business in districts having other refrigeration demands and offering cheap transportation from the orchard to the warehouse. The warehouse also furnishes a means for holding the fruit until favorable market or shipping conditions exist. Because of the comparatively large investment necessary to conduct a cold storage business, warehouses equipped for precooling and storing fruit are not found in any except heavy fruit-producing areas and in the larger commercial centers.

Portable precoolers depend upon the ice in the refrigerator car for refrigeration and are therefore limited to temperatures obtainable with melting ice. They generally work under the disadvantage of short-time operation, for the warm fruit is cooled after it has been loaded in the car, and the car is removed from the yard as soon as possible. They cannot then be expected to cool to as low temperatures as is possible with the warehouse type, but have their direct application where no storage plant is available.

Some of the portable precoolers are adapted to use in the packing house and are capable of being moved from one car to another, but are not constructed to be moved across country. Others are mounted on trucks and can be taken to cars as they stand in the yard. In general, the warehouse types operate under more favorable conditions, but both types of car precoolers tested will effectively remove the first heat if operated for ten or twelve hours, and will be helpful in reducing the temperature in the car if operated six or eight hours. 


\section{FIELD AND PACKING HOUSE TEMPERATURES}

Since the heat in fruit is comparatively difficult to remove after packing, the temperature at which the fruit is packed becomes of increasing importance. In this connection the fruit temperature in the field and the effect of harvesting and handling methods upon the final temperature suggest possible modifications in the picking and removal of the fruit from the orchard and in storing it prior to packing. The temperatures of Winter Nelis pears during the harvesting period while on the trees, are shown in table 18 .

TABLE 18

Temperature Differences of Winter Nelis Peirs in Different Positions on the Tree, and of the Air (August 19, 1927, Mayhews, California)

\begin{tabular}{|c|c|c|c|c|}
\hline Position on tree & Hour of day & $\begin{array}{l}\text { Temperature } \\
\text { of fruit }\end{array}$ & $\begin{array}{c}\text { Air } \\
\text { temperature }\end{array}$ & $\begin{array}{l}\text { Difference } \\
\text { between fruit and } \\
\text { air temperature }\end{array}$ \\
\hline Sun. & \multirow{11}{*}{$\begin{array}{r}\text { 9:30 a.m. } \\
\text { 11:45 a.m. } \\
\text { 11:45 a.m. } \\
\text { 1:50 p.m. } \\
\text { 1:50 p.m. } \\
\text { 4:20 p.m. } \\
\text { 4:20 p.m. } \\
\text { 5:15 p.m. } \\
\text { 5:15 p.m. } \\
\text { 6:50 p.m. } \\
\text { 6:50 p.m. }\end{array}$} & Degrees Fahr. & Degrees Fahr. & Degrees Fahr. \\
\hline Sun & & 94.0 & 900 & $\begin{array}{r}1.0 \\
+4.0\end{array}$ \\
\hline Shade.... & & 83.0 & 84.0 & -1.0 \\
\hline Sun ......... & & 102.0 & 96.0 & +6.0 \\
\hline Shade.... & & 88.0 & 91.5 & -3.5 \\
\hline Sun $\ldots \ldots . . . .$. & & 109.5 & 97.5 & +12.0 \\
\hline Shade... & & 91.5 & 92.5 & -1.0 \\
\hline Sun ....... & & 100.5 & 92.5 & +8.0 \\
\hline Shade... & & 91.5 & 88.5 & +3.0 \\
\hline Eun $\ldots . . .$. & & 81.6 & 79.0 & +5.6 \\
\hline Shade... & & 73.0 & 71.5 & +1.5 \\
\hline
\end{tabular}

The data in table 18 show, as would be expected, that the fruit temperatures became increasingly higher throughout the day until late in the afternoon. The temperatures of the pears in the sun were as much $12^{\circ}$ higher than the air temperatures in the sun, as a result of the heat from the rays of the sun being absorbed and retained.

On the other hand, until late in the afternoon, the temperature of the fruit in the shade tended to be slightly cooler than the corresponding air temperature. This may have resulted first from the tendency of the fruit to lag behind the air both in warming up and in cooling off; and, second, from the cooling effect due to transpiration of water from the surface of the fruit.

The orchard temperatures of the pears were of course reflected in the temperatures of the fruit brought to the packing shed during different hours of the day. As Anjou pears were brought from the field to the unloading platform of the packing shed the average temperatures were taken; these data are shown in table 19. 
TABLE 19

The Temperatures at the Packing House of Anjou Pears Brought from the Field at Differeint Hours of the Day (August 19, 1927,

Mayhews, California)

\begin{tabular}{c|c}
\hline Hours delivered & $\begin{array}{c}\text { Average } \\
\text { temperature } \\
\text { of fruit, } \\
\text { degrees } \\
\text { Fahrenheit }\end{array}$ \\
\hline 9:00 a.m. & 70 \\
10:00 a.m. & 75 \\
11:15 a.m. & 78 \\
1:00 p.m. & 80 \\
$3: 50$ p.m. & 86 \\
4:30 p.m. & 89 \\
5:20 p.m. & 91 \\
$6: 10$ p.m. & 92 \\
$7: 00$ p.m. & 88 \\
$8: 45$ p.m. & 77 \\
\hline
\end{tabular}

There were differences of as much as $22^{\circ}$ in the temperatures of the delivered pears, depending upon the time of the day the fruit was picked. After being placed in the packing shed, however, the loose fruit in lug boxes from the field gradually attained the tempera-

\section{TABLE 20}

Average Drops in Temperature in the Ceinters of Packages of Different Fruits in Refrigerator Cars During Operation of Car Precoolers AND IN WAREhouseis; Degrees Fahrenheit

\begin{tabular}{|c|c|c|c|c|c|c|c|}
\hline Kind of fruit & $\begin{array}{l}\text { Method of } \\
\text { precooling }\end{array}$ & $\begin{array}{l}\text { Hours } \\
\text { of pre- } \\
\text { cooling }\end{array}$ & $\begin{array}{c}\text { Initial } \\
\text { fruit } \\
\text { temper- } \\
\text { ature }\end{array}$ & $\begin{array}{c}\text { Initial } \\
\text { temper- } \\
\text { ature of } \\
\text { cooling } \\
\text { air }\end{array}$ & $\begin{array}{l}\text { Final } \\
\text { fruit } \\
\text { temper- } \\
\text { ature }\end{array}$ & $\begin{array}{l}\text { Final } \\
\text { drop in } \\
\text { fruit } \\
\text { temper- } \\
\text { ature }\end{array}$ & $\begin{array}{l}\text { Total } \\
\text { drop in } \\
\text { fruit } \\
\text { temper- } \\
\text { ature }\end{array}$ \\
\hline Wrapped, packed boxes of pears...... & Warehouse.......... & 45.0 & 68.6 & 39.0 & 34.2 & 31.7 & 34.4 \\
\hline Grapes packed in lugs............................ & Warehouse........... & 33.0 & 59.5 & 40.4 & 34.7 & 29.3 & 24.8 \\
\hline Wrapped, packed boxes of oranges.. & Warehouse.............. & 64.0 & 74.0 & 35.0 & 34.9 & 32.5 & 39.1 \\
\hline Wrapped, packed boxes of pears...... & Car-precooler.... & 6.0 & 69.5 & 67.8 & 59.7 & 53.7 & 9.8 \\
\hline 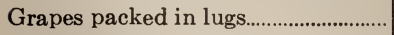 & Car-precooler.... & 3.0 & 60.8 & 54.2 & 51.5 & 49.3 & 9.3 \\
\hline Packed boxes of cherries........................... & Car-precooler.... & 6.0 & 60.0 & 56.0 & 43.3 & 41.4 & 16.7 \\
\hline Packed crates of apricots........................ & Car-precooler.... & 3.5 & 78.0 & 64.2 & 64.4 & 53.4 & 13.6 \\
\hline Wrapped, packed boxed peaches...... & Car-precooler.... & 7.0 & 60.0 & 44.0 & 44.6 & 37.8 & 15.4 \\
\hline Wrapped, packed boxed peaches...... & Iced car only.... & 7.0 & 56.0 & 52.9 & 54.2 & 49.7 & 1.8 \\
\hline Packed boxes of tomatoes...................... & Car-precooler.... & 5.0 & 71.8 & 63.5 & 60.1 & 44.4 & 11.7 \\
\hline Packed crates of cantaloupes............. & Car-precooler.... & 6.0 & 71.9 & 67.8 & 54.9 & 47.2 & 17.0 \\
\hline
\end{tabular}

ture within the shed and followed shed temperature changes rather closely. Representative specimens of this same fruit were left in the packing house overnight, and the next morning the temperature of the fruit in open lugs averaged $60.8^{\circ} \mathrm{F}$. This was nearly $10^{\circ}$ colder 
than the coolest fruit brought from the field the preceding day, and $31^{\circ}$ cooler than the warmest fruit.

In many of the fruit-growing sections of the state, during the harvesting season, there may be as much as $50^{\circ}$ difference in air temperature between the cool hours of the night and the warm hours of the day. It therefore appears to be desirable, when packing house space, loading facilities, car supply, and working conditions permit, to store the fruit picked overnight in the cooler, ventilated parts of the shed in the afternoon.

As a result of the lower night temperatures and the exchange of air surrounding such loose fruit in lug boxes when properly placed to permit ventilation, it can be packed the following morning at a lower initial temperature than would be attained with eight hours of car precooling. Then with the proper use of car precoolers the fruit could be further cooled and started on its journey in a condition approaching the temperatures that are desired en route.

\section{SUMMARY AND CONCLUSIONS}

1. In the warehouse, when the pears were surrounded by air currents having temperatures of $30^{\circ}$ to $35^{\circ} \mathrm{F}$ it required from 45 to 50 hours to cool the centers of the fruit packed in the centers of standard boxes, from $60^{\circ}-75^{\circ} \mathrm{F}$ down to $33^{\circ}-35^{\circ} \mathrm{F}$. Extraction of the heat from wrapped, packed pears is primarily by conduction.

2. Packed boxes of grapes cooled somewhat more rapidly than did packed boxes of pears. With grapes the individual fruits were not so tightly packed together and were unwrapped. Grapes were cooled from $60^{\circ}$ down to $35^{\circ} \mathrm{F}$ in about 33 hours in a warehouse.

3 . The precooling of wrapped oranges packed in standard orange boxes required more time than did any of the other fruits studied. Oranges in the centers of each half of the divided orange box were cooled from $74^{\circ}$ down to $35^{\circ}$ after about 64 hours' storage in warehouse temperatures of $33^{\circ} \mathrm{F}$.

4. Warehouse precooling is adapted to concentrated fruit areas, shipping terminals, or commercial centers, while the portable type of cooler is adapted to those areas not having warehouse facilities, and to small shipping centers or individual packers.

5. Loading of different styles of packages together in one end of the car obstructs air circulatoin and interferes with the effectiveness of car precoolers and the natural circulation of cold air from the ice bunkers. 
6. When the individual fruits of a package are wrapped and tightly placed together, the rate of cooling is retarded as contrasted with that of fruit which is unwrapped and loosely packed. The wrappers serve as insulators and also reduce the space for air movement, and heat is of necessity removed primarily by conduction. Open packages and loose packs permit convection currents, and thus facilitate the removal of heat.

7. Small fruits cool somewhat more rapidly than large fruits. The small fruits have a larger surface per unit of volume, and this permits of more rapid reduction in temperature.

8. Packed, wrapped pears in the centers of standard boxes were cooled from $69.5^{\circ}$ to $59.7^{\circ} \mathrm{F}$ with 6 hours of operation of a car precooler when the car was loaded only with pears. In a mixed load, containing plum, grapes, and pears, the temperature of the pears in the center of the boxes was lowered from $67.5^{\circ}$ to $63.5^{\circ}$ with six hours' operation of the car precooler.

9. Grapes in Los Angeles lugs were cooled from $60.8^{\circ}$ to $52.3^{\circ} \mathrm{F}$ within three hours. Additional data for cherries, apricots, peaches, tomatoes and cantaloupes are shown in table 20.

10. Wrapped, packed peaches with ice only dropped $3.4^{\circ}$ in two hours after loading; when a car precooler was operated during the same interval of time the temperature of the peaches in another similar car dropped $8.2^{\circ} \mathrm{F}$. The fruit in the car with the precooler continued to cool through the afternoon while that in the plain iced car warmed up, until after 7 hours of operation the drops were $1.8^{\circ}$ and $15.4^{\circ}$ respectively.

11. The importance of the initial fruit temperature as influenced by the time of day the fruit is harvested and packed is emphasized in view of the comparative difficulty in removing the heat after the fruit is packed.

12. It costs in addition to transportation charges about $\$ 105.00$ for the delivery of a pre-iced car with average re-icing en route, to Chicago. The delivery of a dry car costs $\$ 21.00$. To manufacture and put ice in a dry car costs about $\$ 4.50$ a ton. The icing with 15,000 pounds would cost about $\$ 34.00$, and this plus the initial cost of the dry car would effect a saving of about $\$ 50.00$ when the car was not re-iced en route. 


\section{ACKNOWLEDGMENTS}

The authors are indebted to certain cooperators in California, who made available fruit and equipment, as follows :

The A. B. Humphrey Company, Mayhews, California.

The Security Warehouse and Cold Storage Co., San Jose, California.

The Vacaville Fruit Growers Association, Vacaville, California.

Frank H. Buck \& Co., Vacaville, California.

The Loomis Fruit Exchange, Sacramento, California.

Pomona Valley Ice and Cold Storage Co., Pomona, California.

Rocky Hill Association Cold Storage and Precooling Plant, Exeter, California.

The Car Precooler Service Co., Los Angeles, California.

To James R. Tavernetti and F. H. Prittie for help received in making the observations and in recording data. 


\section{LITERATURE CITED}

1 Beiach, S. A., and H. J. Eustace.

1909. Cold storage for Iowa-grown apples. Iowa $\Lambda$ gr. Exp. Sta. Bul. 108: 391-414.

2 GORE, H. C.

1911. Studies on fruit respiration. U. S. Dept. Agr., Bur. Chem., Bul. 142: $5-40$.

3 Griffiths, Ezer, and J. H. Auberry.

1928. The heat generated by fruit. Report Food Invest. Board (Great Britain) 1927:88-90.

4 McKaY, A. W.

1918. Loading and transporting western cantaloupes. U. S. Dept. Agr. Bur. Markets Doc. 10:1-116.

5 Overholser, E. L., A. J. Winkler, and H. E. J ACoB.

1925. Factors influeneing the development of internal browning of the Yellow Newtown apple. California Agr. Exp. Sta. Bul. 370:1-40.

6 Powell, G. H.

1905. The transportation of fruits in refrigeration. American Soc. Refrig. Eng. Trans. 1:82-94.

7 RAMSEY, H. J.

1918. Heavy loading of freight ears in the transportation of northwestern apples. U. S. Dept. Agr. Bur. Markets Doc. 13:1-23.

8 READ, F. W., et al.

1924. Refrigeration test trip. California Growers and Shippers Protective League, San Francisco, p. 1-36.

9 Ridley, V. W.

1919. Factors in transportation of strawberries from the Ozark region.

U. S. Dept. Agr. Bur. Markets Doc. 8:10.

10 Stubenrauch, A. V., and H. J. Ramsey.

1913. Bartlett pear precooling and storage investigations in Rogue River Valley. U. S. Dept. Agr. Bur. Pl. Ind. Cir. 114:1-32.

11 Whitehouse, W. E.

1919. Colı storage for Iowa apples. Iowa Agr. Exp. Sta. Bul. 192:179-216. 


\section{BULLETINS}

No.

253. Irrigation and Soil Conditions in the Sierra Nevada Foothills, California.

263. Size Grades for Ripe Olives.

277. Sudan Grass.

279. Irrigation of Rice in California.

283. The Olive Insects of California.

304. A Study of the Effects of Freezes on Citrus in California.

310. Plum Pollination.

313. Pruning Young Deciduous Fruit Trees.

331. Phylloxera-resistant stocks.

335. Cocoanut Meal as a Feed for Dairy Cows and Other Livestock.

343. Cheese Pests and Their Control.

344. Cold Storage as an Aid to the Marketing of Plums, a Progress Report.

346. Almond Pollination.

347. The Control of Red Spiders in Decid uous Orchards.

348. Pruning Young Olive Trees.

349. A Study of Sidedraft and Tractor Hitches.

353. Bovine Infectious Ahortion, and Associated Diseases of Cattle and Newborn Calves.

354. Results of Rice Experiments in 1922 .

357. A Self-Mixing Dusting Machine for Applying Dry Insecticides and Fungicides.

361. Preliminary Yield Tables for SecondGrowth Redwood.

362. Dust and the Tractor Engine

363. The Pruning of Citrus Trees in California.

364. Fingicidal Dusts for the Control of Bunt.

366. Twrkish Tobacco Culture, Curing, and Marketing.

367. Methods of Harvesting and Irrigation in Relation to Moldy Walnuts.

368. Bacterial Decomposition of Olives During Pickling.

369. Comparison of Woods for Butter Boxes.

370. Factors Influencing the Development of Internal Browning of the Yellow Newtown Apnle.

371. The Relative Cost of Yarding Small and Large Timber.

373. Pear Pollination.

374. A Survey of Orchard Practices in the Citrus Industry of Southern California.

380. Growth of Eucalyptus in California Plantations.

385. Pollination of the Sweet Cherry.

386. Pruning Bearing Deciduous Fruit Trees.

388. The Principles and Practice of SunDrying Fruit.

389. Berseem or Egyptian Clover.

390. Harvesting and Packing Grapes in California.

391. Machines for Coating Seed Wheat with Copper Carbonate Dust.

392. Fruit Juice Concentrates.

393. Crop Sequences at Davis.

394. I. Cereal Hay Production in California. II. Feeding Trials with Cereal Hays.

395. Bark Diseases of Citrus Trees in California.

396. The Mat Bean, Phaseolus Aconitifolius.

397. Manufacture of Roquefort Type Cheese from Goat's Milk.

400. The Utilization of Surplus Plums.

405. Citrus Culture in Central California.

406. Stationary Spray Plants in California.

407. Yield. Stand, and Volume Tables for White Fir in the California Pine Region.
No.

408. Alternaria Rot of Lemons.

409. The Digestibility of Certain Fruit By Products as Determined for Ruminants. Part I. Dried Orange Pulp and Raisin Pulp.

410. Factors Influencing the Quality of Fresh Asparagus After it is Harvested.

412. A Study of the Relative Value of Certain Root Crops and Salmon Oil as Sources of Vitamin A for Poultry.

414. Planting and Thinning Distances for Deciduous Fruit Trees.

415. The Tractor on California Farms.

416. Culture of the Oriental Persimmon in California.

418. A Study of Various Rations for Fin. ishing Range Calves as Baby Beeves.

419. Economic Aspects of the Cantaloupe Industry.

420. Rice and Rice By-Products as Feeds for Fattening Swine.

421. Beef Cattle Feeding 'I'rials, 1921-24.

423. Apricots (Series on California Crops and Prices).

425. Apple Growing in California.

426. Apple Pollination Studies in California.

427. The Value of Orange Pulp for Milk Production.

428. The Relation of Maturity of California Plums to Shipping and Dessert Quality.

430. Range Grasses in California.

431. Raisin By-Products and Bean Screenings as Feeds for Fattening Lambs.

432. Some Economic Problems Involved in the Pooling of Fruit.

433. Power Requirements of Electrically Driven Dairy Manufacturing Equipment.

434. Investigations on the Use of Fruits in Ice Cream and Ices.

435. The Problem of Securing Closer Relationship between Agricultural Devel. opment and Irrigation Construction.

436. I. The Kadota Fig. II. The Kadota Fig Products.

438. Grafting Affinities with Special Reference to Plums.

439. The Digestibility of Certain Fruit ByProducts as Determined for Ruminants. II. Dried Pineapple Pulp, Dried Lemon Pulp, and Dried Olive Pulp.

440. The Feeding Value of Raisins and Dairy By-Products for Growing and Fattening Swine.

444. Series on California Crops and Prices: Beans.

445. Economic Aspects of the Apple Industry.

446. The Asparagus Industry in California.

447. A Method of Determining the Clean Weights of Individual Fleeces of Wool.

448. Farmers' Purchase Agreement for Deep Well Pumps.

449. Economic Aspects of the Watermelon Industry.

450. Irrigation Investigations with Field Crops at Davis, and at Delhi, California, 1909-1925.

451. Studies Preliminary to the Establishment of a Series of Fertilizer Trials in a Bearing Citrus Grove.

452. Economic Aspects of the Pear Industry.

453. Series on California Crops and Prices: Almonds.

454. Rice Experiments in Sacramento Valley, 1922-1927. 
No.

455. Reclamation of the Fresno Type of Black-Alkali Soil.

456. Yield, Stand and Volume Tables for Red Fir in California.

458. Factors Influencing Percentage Calf Crop in Range Herds.

459. Economic Aspects of the Fresh Plum Industry.

460. Series on California Crops and Prices: Lemons.

461. Series on California Crops and Prices: Economic Aspects of the Beef Cattle Industry.

462. Prune Supply and Price Situation.

464. Drainage in the Sacramento Valley Rice Fields.
No.

465. Curly Top Symptoms of the Sugar Beet.

466. The Continuous Can Washer for Dairy Plants.

467. Oat Varieties in California.

468. Sterilization of Dairy Utensils witl Humidified Hot Air.

469. The Solar Heater.

470. Maturity Standards for Harvesting Bartlett Pears for Eastern Shipment.

471. The Use of Sulfur Dioxide in Shipping Grapes.

474. Factors Affecting the Cost of Tractor Logging in the California Pine Region.

475. Walnut Supply and Price Situation.

\section{CIRCULARS}

No.

115. Grafting Vinifera Vineyards.

117. The Selection and Cost of a Sinall Pumping Plant.

127. House Fumigation.

129. The Control of Citrus Insects.

164. Small Fruit Culture in California.

166. The County Farm Bureau.

178. The Packing of Apples in California.

203. Peat as a Manure Substitute.

212. Salvaging Rain-Damaged Prunes.

230. Testing Milk. Cream, and Skim Milk for Butterfat.

232. Harvesting and Handling California Cherries for Eastern Shipment.

239. Harvesting and Handling Apricots and Plums for Eastern Shipment.

240. Harvesting and Handling California Pears for Eastern Shipment.

241. Harvesting and Handling California Peaches for Eastern Shipment.

243. Marmalade Juice and Jelly Juice from Citrus Fruits.

244. Central Wire Bracing for Fruit Trees.

245. Vine Pruning Systems.

248. Some Common Errors in Vine Pruning and Their Remedies.

249. Replacing Missing Vines.

250. Measurement of Irrigation Water on the Farm.

253. Vineyard Plans.

255. Leguminous Plants as Organic Fertilizers in California Agriculture.

257. The Small-Seeded Horse Bean (Vicia faba var. minor)

258. Thinning Deciduous Fruits.

259. Pear By-Products.

261. Sewing Grain Sacks.

262. Cabbage Production in California.

263. Tomato Production in California.

265. Plant Disease and Pest Control.

266. Analyzing the Citrus Orchard by Means of Simple Tree Records.
No.

269. An Orchard Brusli Burner.

270. A Farm Septic Tank.

276. Home Canning.

277. Head, Cane, and Cordon Pruning of Vines.

278. Olive Pickling in Mediterranean Countries.

279 The Preparation and Refining of Olive Oil in Southern Europe.

282. Prevention of Insect Attack on Stored Grain.

284. The Almond in California.

287. Potato Production in California.

288. Phylloxera Resistant Vineyards.

289. Oak Fungus in Orchard Trees.

290. The Tangier Pea.

292. Alkali Soils.

294. Propagation of Deciduous Fruits.

295. Growing Head Lettuce in California.

296. Control of the California Gronnd Squirrel.

298. Possibilities and Limitations of Cooperative Marketing.

300. Coccidiosis of Chickens.

301. Buckeye Poisoning of the Honey Bee.

302. The Sugar Beet in California.

304. Drainage on the Farm.

305. Liming the Soil.

307. American Foulbrood and Its Control.

308. Cantaloupe Production in California.

309. Fruit Tree and Orchard Judging.

310. The Operation of the Bacteriological Laboratory for Dairy Plants.

311. The Improvement of Quality in Figs.

312. Principles Governing the Choice, Operation and Care of Small Irrigation Pumping Plants.

313. Fruit Juices and Fruit Juice Beverages.

314. Termites and Termite Damage.

315. The Mediterranean and Other Fruit Flies. 